解説

\title{
多成分希士類永久磁石化合物メゾスコピック粒子の合成
}

\author{
T. Thuy TRINH*，Jungryang KIM，佐藤＼cjkstart良太，松本 憲志，寺西 利治* \\ 京都大学化学研究所， $=611-0011$ 宇治市五ケ庄.
}

\section{Synthesis of Mesoscopic Particles of Multi-Component Rare Earth Permanent Magnet Compounds}

\author{
T. Thuy TRINH*, Jungryang KIM, Ryota SATO, Kenshi MATSUMOTO and Toshiharu TERANISHI* \\ Institute for Chemical Research, Kyoto University, Gokasho, Uji 611-0011, Japan.
}

Received April 14, 2021; Revised August 5, 2021; Accepted August 5, 2021

\begin{abstract}
Multielement rare earth (R)-transition metal (T) intermetallics are arguably the next generation of highperformance permanent magnetic materials for future applications in energy-saving and renewable energy technologies. Pseudobinary $\mathrm{Sm}_{2} \mathrm{Fe}_{17} \mathrm{~N}_{3}$ and $(\mathrm{R}, \mathrm{Zr})(\mathrm{Fe}, \mathrm{Co}, \mathrm{Ti})_{12}(\mathrm{R}=\mathrm{Nd}, \mathrm{Sm})$ compounds have the highest potential to meet current demands for rare-earth-element-lean permanent magnets (PMs) with ultra-large energy product and operating temperatures up to $200^{\circ} \mathrm{C}$. However, the synthesis of these materials, especially in the mesoscopic scale for maximizing the maximum energy product $\left((B H)_{\max }\right)$, remains a great challenge. Nonequilibrium processes are apparently used to overcome the phase-stabilization challenge in preparing the R-T intermetallics but have limited control of the material's microstructure. More radical bottom-up nanoparticle approaches based on chemical synthesis have also been explored, owing to their potential to achieve the desired composition, structure, size, and shape. While a great achievement has been made for the $\mathrm{Sm}_{2} \mathrm{Fe}_{17} \mathrm{~N}_{3}$, progress in the synthesis of $(\mathrm{R}, \mathrm{Zr})(\mathrm{Fe}, \mathrm{Co}, \mathrm{Ti})_{12}$ magnetic mesoscopic particles (MMPs) and R-T/T exchange-coupled nanocomposites (NCMs) with substantial coercivity $\left(H_{\mathrm{c}}\right)$ and remanence $\left(M_{\mathrm{r}}\right)$, respectively, remains marginal.
\end{abstract}

\section{KEY WORDS}

multielement rare earth-transition metal intermetallics, permanent magnet, chemical synthesis, magnetic mesoscopic particle, exchange-coupled nanocomposite

\section{1 緒 言}

現在の高性能永久磁石である $\mathrm{Nd}_{2} \mathrm{Fe}_{14} \mathrm{~B}\left(P 4_{2} / m n m\right)$ 化合物 は, キュリー温度 $T_{\mathrm{c}}$ が $313^{\circ} \mathrm{C}$ と比較的低く ${ }^{1,2}$, その焼結磁石 $\left(\mathrm{Nd}_{2} \mathrm{Fe}_{14} \mathrm{~B}: 0.982 \mathrm{vol} \%, \mathrm{O}_{2}: 600 \mathrm{ppm}\right.$, 結晶粒配向 : 0.991) の室温 $(B H)_{\max }$ 值 $474 \mathrm{~kJ} \mathrm{~m}^{-3}$ は理論限界值 $520 \mathrm{~kJ} \mathrm{~m}^{-3}$ に近づい ているため ${ }^{3)}, \mathrm{Nd}_{2} \mathrm{Fe}_{14} \mathrm{~B} よ り$ 高温動作（通常は $200^{\circ} \mathrm{C}$ ) で高 効率電気モーターや発電機を駆動できる高性能永久磁石化合 物が強く求められている ${ }^{4-8)}$. 一軸結晶磁気異方性を有する多 元素 $\mathrm{R}-\mathrm{T}$ 金属間化合物は, 化合物本来のもっている極めて 大きな intrinsic な磁気特性を有する唯一の候補であり， $\mathrm{R}$ 副 格子の $4 f$ 電子の強いスピン軌道相互作用（SOC）が大きな

* Corresponding author, E-mail: trinh@scl.kyoto-u.ac.jp, teranisi@scl. kyoto-u.ac.jp

本論文のオリジナルの論文は “Science and Technology of Advanced Materials (STAM)”, Vol. 22, No. 1, pp. 37-54 に掲載済みである.
一軸異方性磁場 $H_{\mathrm{a}}$ と大きな磁気モーメントに, $\mathrm{T}$ 副格子の $3 d$ 電子の強い交換相互作用が大きな飽和磁化 $M_{\mathrm{s}}$ と高い $T_{\mathrm{c}}$ に 寄与している, ${ }^{9,10)}$. その中で, $\mathrm{R}_{2} \mathrm{~T}_{17}\left(\mathrm{Th}_{2} \mathrm{Zn}_{17}\right.$ 型, $\left.R-3 m\right)$ およ び $\mathrm{RT}_{12}\left(\mathrm{ThMn}_{12}\right.$ 型, I4/mmm) 化合物は, $\mathrm{Nd}_{2} \mathrm{Fe}_{14} \mathrm{~B}$ 化合物を 凌駕する優れた磁気特性を有しており，希薄希土類元素永久 磁石に必要とされる条件を十分満たしている (Fig. 1) $)^{1,2,11-22) .}$

マイクロ磁性として知られるメゾスコピック領域 (sub$\mu \mathrm{m} \sim 10 \mu \mathrm{m})$ の磁性には, 微細構造等の合成過程に左右され る多彩な extrinsic な挙動が見られる， $H_{\mathrm{c}}$ は永久磁石において 非常に重要な extrinsic な特性であり, Brownの逆説 ${ }^{23,24)}$ “ $H_{\mathrm{c}}$ は欠陥により $\alpha H_{\mathrm{a}}$ に減少する $(\alpha(0 \leq \alpha<1)$ は微細構造の 詳細を記述する因子 $\left.{ }^{25-29)}\right) ” に$ に従い, 材料の実際の構造で決 まる，磁性メゾスコピック粒子，特に磁性ナノ粒子は，高 性能な異方性永久磁石創製に用いることができる構成要素 として重要であり ${ }^{30-32)}$ ，そのユニークな特徴として，粒径に 


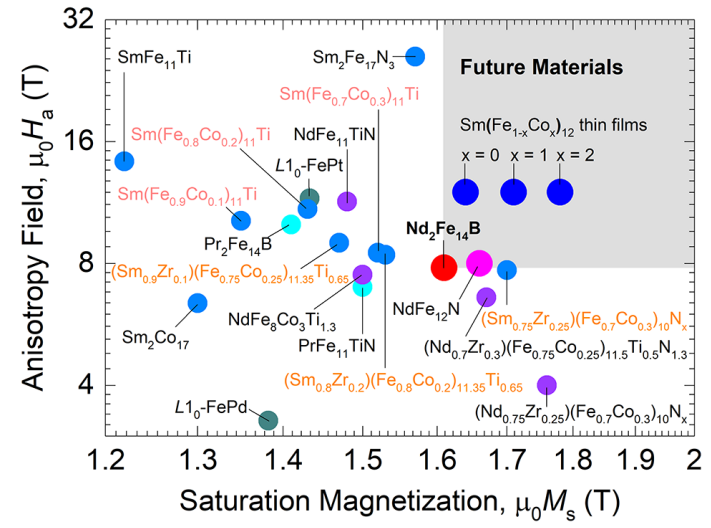

Fig. 1 Room-temperature intrinsic magnetic properties of up-to-date representative compounds. The $\mathrm{Sm}\left(\mathrm{Fe}_{1-x} \mathrm{Co}_{x}\right)_{12}$ and $\mathrm{NdFe}_{12} \mathrm{~N}$ compounds are in the form of thin film; the other compounds are in the form of micropowders. Data are incorporated with [1,11-22].

依存する保磁力が挙げられる。すなわち，結晶粒が強い立 方異方性をもっている場合, 単一ドメインの $H_{\mathrm{c}}$ は超常磁性 臨界サイズ $\left(D_{\mathrm{sp}}\right)$ 以上で $H_{\mathrm{c}} \sim 1-\left(D_{\mathrm{sp}} / \mathrm{D}\right)^{3 / 2}$ に従い増加し, $D_{\mathrm{sd}} \approx 72 \sqrt{A_{\mathrm{ex}} K_{1}} / \mu_{0} M_{\mathrm{s}}^{2}$ ( $A_{\mathrm{ex}}$ : 交換スティフネス, $K_{1}$ : 異方性 定数）で与えられる単一ドメイン臨界サイズ $\left(D_{\mathrm{sd}}\right)$ で最大 となり, $H_{\mathrm{c}} \sim 1 / D^{\mathrm{n}}$ に従い減少する ${ }^{33-36)}$. 代表的な $\mathrm{R}_{2} \mathrm{~T}_{17}$ お よ び $\mathrm{RT}_{12}$ 化合物の粒径依存保磁力の例を Fig. 2 に示す ${ }^{37-50)}$. 結 晶相安定化の課題があるため, R-T 多元素材料の微細構造制 御は依然として重要であるが，R-T 永久磁石材料は 1960 年 代から開発されており ${ }^{51)}, \mathrm{Nd}_{2} \mathrm{Fe}_{14} \mathrm{~B}$ 化合物が 1984 年の発見 以来利用され続けている ${ }^{52-55}$.

多元素 $\mathrm{R}-\mathrm{T}$ 金属間化合物，特に $\mathrm{RT}_{12}$ 化合物は，その複雑 な結晶構造，狭い組成範囲かつ高温（700-1200 $\left.{ }^{\circ} \mathrm{C}\right)$ で形成 される結晶相，および大気下での低い化学的安定性のため, 合成が非常に困難である ${ }^{56-60)}$. 一般に，平衡相 R-T 金属間化 合物は，合金液体の低速冷却や鋳造インゴットの長時間高温 アニーリングなど，平衡状態図の枠組みでの平衡プロセスに よって合成できる，金属間化合物を合成するには，アーク溶 解法または誘導溶解法とそれに続くアニーリングを利用する 後者のプロセスが有用である ${ }^{12,13,16-19,22,37,58,59,61)}$. しかし，単一 相を生成させる厳密な平衡条件の実現は難しく，金属 $\mathrm{R}$ 打 よび $\mathrm{T} か ゙$ 異なる複数の平衡相を容易に形成するため, 平衡 プロセスではしばしば不純物が生成し，長時間高温アニーリ ングにより微細構造，特に粒径が制御しにくくなる．対照的 に，非平衡プロセスは，限度はあるものの，準安定化合物た けでなく不純物を含まない望みの結晶構造と微細構造をもつ 金属間化合物の合成に適している ${ }^{61)}$. 最初にアモルファス相 を形成させ，次に適切な温度でアニールする方法が最も一般 的である ${ }^{14,40-50)}$. アニーリングにより，さまざまな極限非平 衡条件で可能となる準安定相の形成と, 自由エネルギー極小 值に対応する準安定相一平衡相間の動的変換が促進される. 相の結晶学的対称性により，相形成のための自由エネルギー の極小值には差異が生じる。もちろん，組成や原子間結合工 ネルギーなどの他の要因も，相の形成と安定性に重要な役割
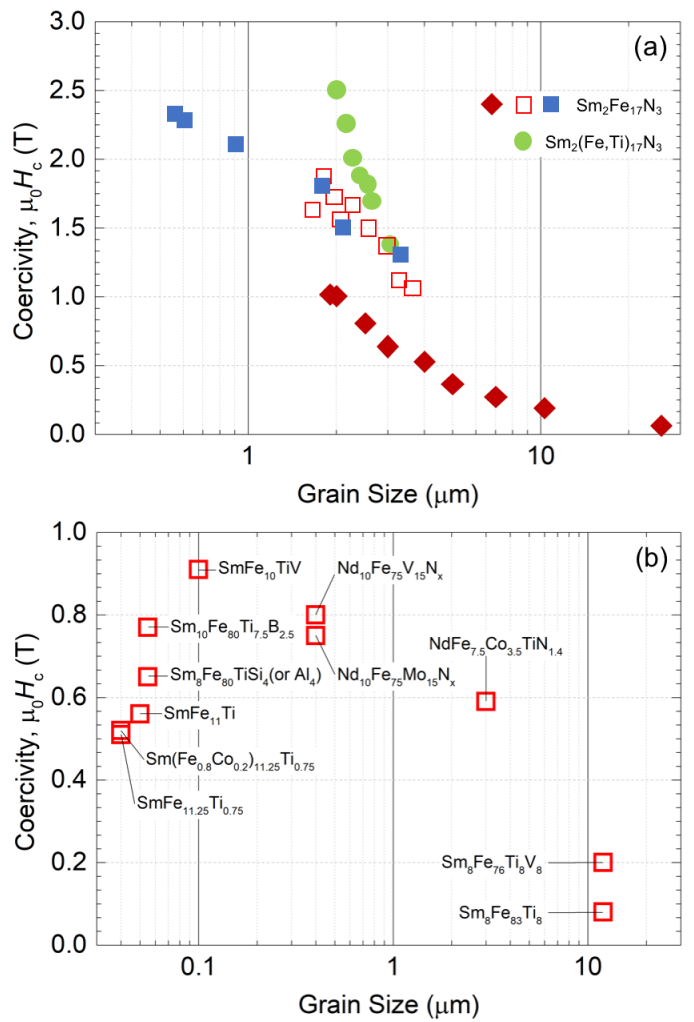

Fig. 2 Grain size dependence of room-temperature coercivity. (a) $\mathrm{Sm}_{2} \mathrm{Fe}_{17} \mathrm{~N}_{3}$ compounds. (b) $\mathrm{R}(\mathrm{Fe}, \mathrm{M})_{12} \mathrm{X}_{x}(\mathrm{R}=\mathrm{Nd}, \mathrm{Sm} ; \mathrm{M}=\mathrm{Ti}, \mathrm{V}, \mathrm{Co}, \mathrm{Mo}, \mathrm{Al}$, Si: phase stabilizing elements; $X=N, B$ ) compounds. (a) Reprinted with permission from [39]. Copyright 2020 Elsevier. (b) Data are incorporated with [40-50].

を果たす，R-T化合物がとる合金構造の結晶学的対称性は, アモルファス, $\mathrm{CaCu}_{5}$ 型 $(P 6 / \mathrm{mmm}), \mathrm{TbCu}_{7}$ 型 $(P 6 / \mathrm{mmm})$, $\mathrm{Th}_{2} \mathrm{Ni}_{17}$ 型 $\left(P 6_{3} / m m c\right), \mathrm{Nd}_{2} \mathrm{Fe}_{14} \mathrm{~B}$ 型 $\left(P 4_{2} / m m m\right), \quad \mathrm{ThMn}_{12}$ 型 $(I 4 / m m m), \mathrm{Th}_{2} \mathrm{Zn}_{17}$ 型 $(R-3 m), \mathrm{Nd}_{3}(\mathrm{Fe}, \mathrm{Ti})_{29}$ 型 $\left(A_{2} / m\right)$ の順 で低下する ${ }^{56,57,61)}$ ，合金組成や合成条件によっては，最後の 五つの平衡相に抒ける生成自由エネルギーの極小值の差は非 常に小さくなり，ある組成㧍よびプロセス条件下では通常， 一つの平衡相のみが形成される ${ }^{61)}$. R-T 準安定相执よび平衡 相の中で対称性が最も高い $\mathrm{CaCu}_{5}$ 型 $(P 6 / \mathrm{mmm})$ 構造は, 次 のように R 原子をダンベルペアとして知られている $\mathrm{T}$ 原子 ペアに置換することでさまざまな構造の R-T 化合物を得る ことができる ${ }^{5,57)}$ :

$$
\begin{aligned}
& 2 \mathrm{RT}_{5}-\mathrm{R}+2 \mathrm{~T}=\mathrm{RT}_{12}(I 4 / m m m) \\
& 3 \mathrm{RT}_{5}-\mathrm{R}+2 \mathrm{~T}=\mathrm{R}_{2} \mathrm{~T}_{17}\left(R-3 m \text { or } P 6_{3} / m m c\right) \\
& 5 \mathrm{RT}_{5}-2 \mathrm{R}+4 \mathrm{~T}=\mathrm{R}_{3} \mathrm{~T}_{29}\left(A_{2} / m\right)
\end{aligned}
$$

ほとんどの R-T 化合物では，準安定 $\mathrm{CaCu}_{5}$ 相は狭い温度範 囲で形成されるため，実験的にはほとんど観察されない． $\mathrm{CaCu}_{5}$ 相の形成は, 非常に遅い加熱速度で短時間注意深くア ニールすることで観察できるが ${ }^{46)}$ ，準安定 $\mathrm{TbCu}_{7}$ 相は十分に 広い温度範囲で形成されるため，さまざまな合成プロセスで 観察できる ${ }^{14,40,43}$. 実際には，準安定化合物は通常，アモル ファス相の結晶化温度よりもわずかに高いアニール温度で結 
晶化し，より高いアニール温度でさらに安定な化合物に動的 に変態する ${ }^{61)}$. したがって，ある組成揖よびプロセス条件下 で適切な焼成温度を選択することが，所望の金属間化合物形 成を促進するために不可欠である，以下のプロセスは，上記 の方法に基づくものである：メカニカルアロイング；高エネ ルギーボールミリング（HEBM）打よび界面活性剤支援ボー ルミリング（SABM）を含むメカニカルミリング；急冷凝固 /溶融紡糸; 水素化不均化脱水素再結合 $(\mathrm{HDDR})^{611}$. これら のプロセスは, 微粉末の大量合成に広く利用されているが, 材料の微細構造の制御には限度がある。 DC マグネトロンス パッタリング非平衡プロセスは, 準安定 $\mathrm{RT}_{12}$ 膜の形成によ く使われている ${ }^{15,20)}$. 他の二つの有力な非平衡プロセスとし て固相抒よび固体ガス反応が挙げられるが ${ }^{19,37-39), ~ こ れ ら に ~}$ ついては以下で説明する。 ボトムアップ合成法の中で, 化学 合成は，磁性メゾスコピック粒子の組成，構造，粒径，形状 を制御して合成できる最も汎用性の高い方法である ${ }^{30-32,622}$.

磁性ナノ粒子の液相合成とそれに続く固相反応の最近の進歩 により，R-T 金属間化合物合成における相安定化の課題が克 服され，極めて大きな室温 $H_{\mathrm{c}}$ を示すいくつかの二元 $\mathrm{R}-\mathrm{T}$ 金 属間化合物磁性メゾスコピック粒子 $\left(\mathrm{SmCo}_{5}, \mathrm{Sm}_{2} \mathrm{Co}_{17}\right.$ など $)$ が合成されている ${ }^{(2,63)}$. ここでは, 最も挑戦的な多元素擬二 元 $\mathrm{R}_{2} \mathrm{~T}_{17}$ および $\mathrm{RT}_{12}$ 金属間化合物の化学合成に関する最近の 進展のなかで, 我々が進めている研究の概要を, 粒径と組成 制御に重点を置いて紹介する。この総説では, 磁性メゾスコ ピック粒子の微細構造制御の前駆体としてのナノ粒子を用い る根拠を含め, $\mathrm{Sm}_{2} \mathrm{Fe}_{17} \mathrm{~N}_{3}$ お よび $(\mathrm{R}, \mathrm{Zr})(\mathrm{Fe}, \mathrm{Co}, \mathrm{M})_{12}(\mathrm{R}=\mathrm{Nd}$, $\mathrm{Sm} ; \mathrm{M}=\mathrm{Ti}, \mathrm{V}, \mathrm{Cr}, \mathrm{Mn}, \mathrm{Co}, \mathrm{Mo}, \mathrm{W}, \mathrm{Al}, \mathrm{Si}, \mathrm{Ga})$ 磁性メゾスコピッ ク粒子に関する最近の研究成果を述べる。 また, 磁気硬磁性 〈軟磁性交換結合 R-T/Tナノコンポジット磁石の化学合成 に関する研究についても紹介する.

\section{2 ナノ構造前駆体の合成}

$\mathrm{R}$ カチオンの大きな負の還元電位， $\mathrm{R}$ および $\mathrm{T}$ カチオンの 還元電位の大きな差異，および $\mathrm{R}$ 金属の低い化学的安定性 により，液相化学反応によって R-T 金属間化合物を直接合 成することは不可能である．別の化学合成法として，まず化 学的に安定で液相反応が容易なナノ構造前駆体を合成後, 前 駆体の還元拡散反応を行う方法がある。組成，粒径，形状が 制御可能な単分散ナノ構造前駆体は, 磁性メゾスコピック粒 子の微細構造を決定する上で重要であり,コア@シェル， 内包化, ドープ, 混合酸化物ナノ粒子などの構造様式により， それぞれ優位性がある。

$\mathrm{T}$ 金属または $\mathrm{T}$ 酸化物（T-O) コアと R 酸化物（R-O) シェルからなるコア@シェルナノ構造（以下 $\mathrm{T} / \mathrm{T}-\mathrm{O} @ \mathrm{R}-\mathrm{O}$ ナノ粒子と表記）は，通常二段階反応で合成される：つま り， T または $\mathrm{T}-\mathrm{O} ナ ノ$ 粒子を合成後, ナノ粒子表面に R-O を堆積させて合成する．Sunらが報告しているように，粒径 が $10 \mathrm{~nm}$ 未満の Co $(F m-3 m)$ やアモルファス $\mathrm{Fe}$ ナノ粒子は, $\mathrm{Co}_{2}(\mathrm{CO})_{8}$ や $\mathrm{Fe}(\mathrm{CO})_{5}$ の熱分解により容易に合成できる ${ }^{64,65)}$. 長さ 200-300 nm, 平均直径 $20 \mathrm{~nm}$ の Co $\left(P 6_{3} / m m c\right)$ ナノロッ
ドは，1,2-ブタンジオール中ヘキサデシルアミン存在下， Ru 触媒によるラウリン酸コバルトのソルボサーマル反応で合成 できる ${ }^{66)}$. Carpenterらは, クエン酸ナトリウム存在下, 室温 で $\mathrm{FeSO}_{4}$ の $\mathrm{NaBH}_{4}$ 還元により，粒径 $200 \mathrm{~nm}$ のアモルファス $\mathrm{Fe}$ ナノ粒子を合成した ${ }^{67)}$. 約十一数百 $\mathrm{nm}$ の広い範囲で粒径 制御可能な一連の $\mathrm{Fe}-\mathrm{O}$ ナノ粒子が，以下の方法で合成され ている，オレイン酸およびオレイルアミン存在下, Fe (acac) $(\mathrm{acac}=$ アセチルアセトナート) の還元熱分解で反応温度を 制御することにより，ウスタイト $\mathrm{FeO}(F m-3 m)$ ナノ粒子 の粒径を 14-100 nmの範囲で制御できる ${ }^{68)}$ ，立方体状マグネ タイト $\mathrm{Fe}_{3} \mathrm{O}_{4}(F d-3 m)$ ナノ粒子は, オレイン酸存在下, ベ ンジルエーテル溶媒中 $290^{\circ} \mathrm{C}$ で $\mathrm{Fe}(\mathrm{acac})_{3}$ を熱分解すること で合成することができ ${ }^{69)}$, Fig. 3 に示すように，オレイン酸 濃度を変化させることにより 20-200 nm の範囲で粒径制御 が可能である ${ }^{70)}$. Hyeon らは, 沸点の異なるさまざまな溶媒 中でオレイン酸 $\mathrm{Fe}(\mathrm{III})$ 錯体を熱分解することにより，粒径 5-20 nm で制御可能な微細 $\mathrm{Fe}_{3} \mathrm{O}_{4}$ ナノ粒子の大量合成法を開 発した ${ }^{71)}$ ，ナノ構造前駆体結晶面の表面エネルギーを考慮す ることで還元拡散反応における金属原子の相互拡散を決定で きるため，さまざまな形状のナノ粒子を用いることで，還元 拡散反応に拈けるナノ構造前駆体の反応性を調整できる。こ れまでに, Fig. 4 に示すように, CPC $(\mathrm{CPC}=$ 塩化セチルピ リジニウム）濃度を変化させることにより, 立方体から切 頂六面体，立方八面体，切頂八面体，八面体まで，合理的
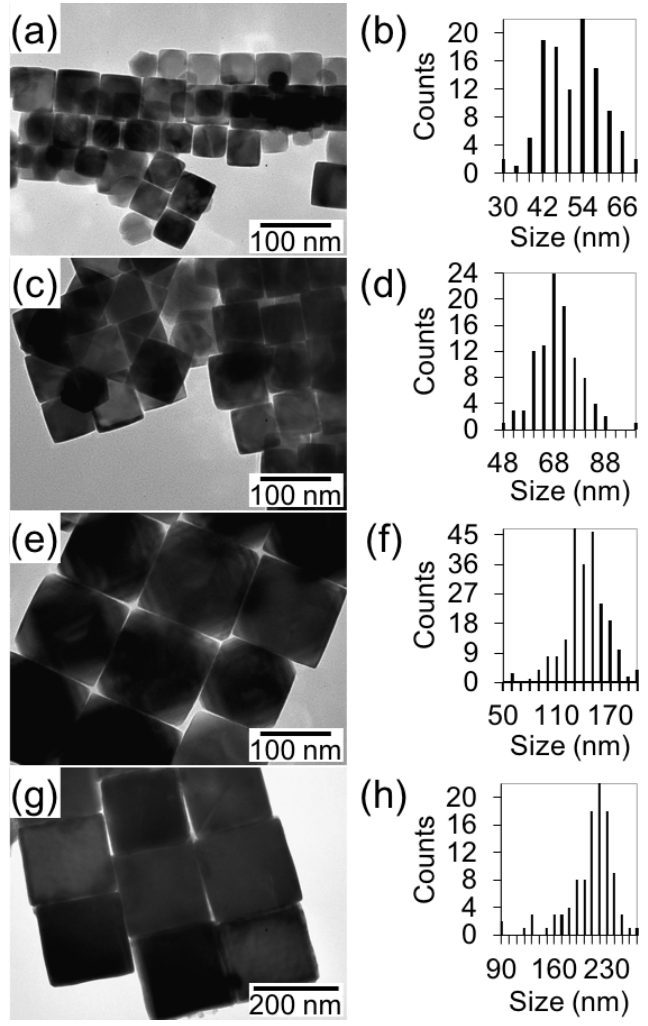

(h)

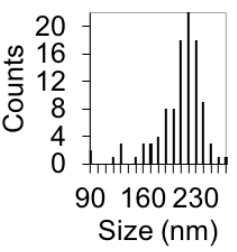

Fig. 3 Size evolution of $\mathrm{Fe}_{3} \mathrm{O}_{4}(F d-3 m)$ NPs. (a, c, e, g) Transmission electron microscopy (TEM) images and $(b, d, f, h)$ size distributions. Reprinted with permission from [70]. Copyright 2020 Wiley $\mathrm{VCH}$ 

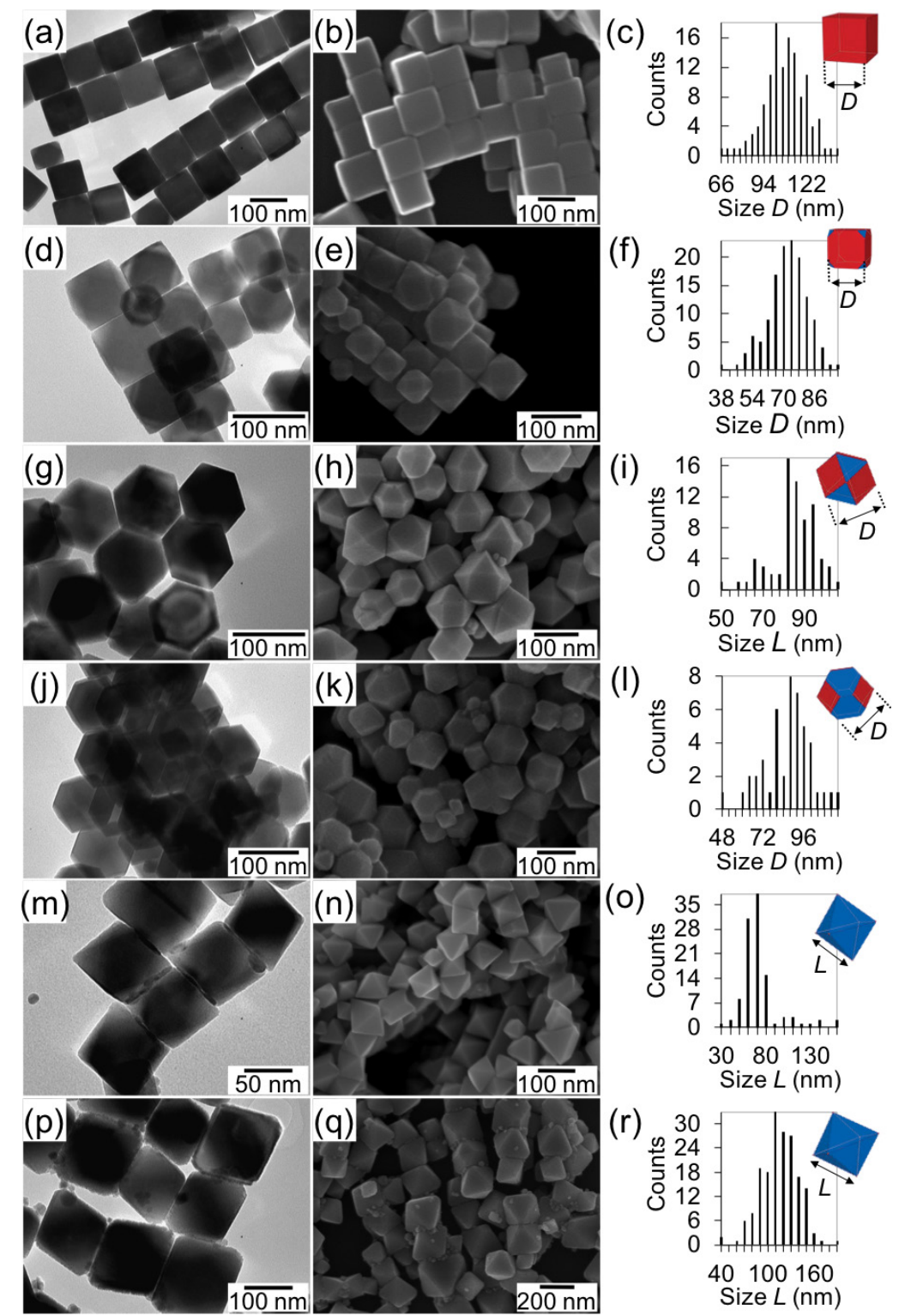

Fig. 4 Shape evolution of $\mathrm{Fe}_{3} \mathrm{O}_{4}(F d-3 m)$ NPs: $(\mathrm{a}-\mathrm{c})$ cubes, $(\mathrm{d}-\mathrm{f})$ truncated cubes, $(\mathrm{g}-\mathrm{i})$ cuboctahedra, $(\mathrm{j}-1)$ truncated octahedra, $(\mathrm{m}-\mathrm{o})$ octahedra with small size, and (p-r) octahedra with large size. (a, d, g, j, m, p) TEM images, (b, e, h, k, n, q) Scanning electron microscopy (SEM) images, and (c, f, i, l, o, r) size distributions. Insets show the $\{100\}$ and $\{111\}$ planes in red and blue, respectively. Reprinted with permission from [70]. Copyright $2020 \mathrm{Wiley}$ VCH.

に形状制御された $\mathrm{Fe}_{3} \mathrm{O}_{4}(F d-3 m)$ ナノ粒子が合成されてい る ${ }^{70)}$. Coのような遷移金属コアが合成されれば，Fig. $5 \mathrm{a} に$ 示すように, 1-オクタデセン中 $300^{\circ} \mathrm{C}$ での $\mathrm{Sm}(\mathrm{acac})_{3}$ の熱分 解により，アモルファス $\mathrm{Sm}-\mathrm{O}$ シェルを堆積させることがで きる ${ }^{65,66)}$. 粒子状の $\mathrm{Sm}-\mathrm{O}$ ナノ粒子の均一核形成を抑制する ため, 昇温速度を $2^{\circ} \mathrm{C} \mathrm{min}^{-1}$ 程度に遅くする必要がある。こ の方法は, Fig. 5b に示すような $\mathrm{Fe}_{3} \mathrm{O}_{4} @ \mathrm{Sm}-\mathrm{O}$ ナノ粒子合成 に拡張することができ ${ }^{72)}, \mathrm{Fe} / \mathrm{Sm}$ モル比は $\mathrm{Sm}(\mathrm{acac})_{3}$ と $\mathrm{Fe}_{3} \mathrm{O}_{4}$ ナノ粒子の相対量を調整することで制御可能である。

T/T-O@R-Oナノ構造は, すでに確立されている溶液化 学合成法により数 $\mathrm{nm} \sim 1 \mu \mathrm{m}$ のスケールで粒径を制御でき るため，永久磁石創製には非常に魅力的である。ただし，

この方法は二元 R-T 磁性メゾスコピック粒子合成ではかな り成功しているが ${ }^{65,66)}$, 合成プロセスには収率が低くなる

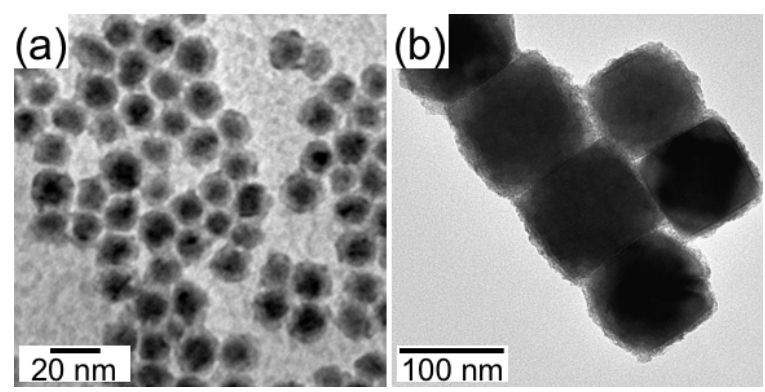

Fig. 5 Chemically-synthesized core@shell nanostructured precursors. (a, b) TEM images of Co@Sm-O (Co core: $F d-3 m, 8 \mathrm{~nm}$; Sm:Co $=1: 4.3$ at $\%)\left(\right.$ a) and $\mathrm{Fe}_{3} \mathrm{O}_{4} @ \mathrm{Sm}-\mathrm{O}\left(\mathrm{Fe}_{3} \mathrm{O}_{4}\right.$ core: $F d-3 m, 79 \mathrm{~nm}$; $\mathrm{Sm}: \mathrm{Fe}=1: 11.5 \mathrm{at} \%$ ) (b). (a) Reprinted with permission from [65]. Copyright 2020 Wiley VCH. (b) Reproduced with permission from [72]. Copyright 2020 the Chemical Society of Japan. 
多段階反応が含まれ， $\mathrm{R} / \mathrm{T}$ 比が十分に制御されないため, 二元素より多元素の R-T 磁性メゾスコピック粒子には不適 切であろう。より精密な組成制御と粒径制御のため, 結晶 またはアモルファスの R-O と T-O が一つのナノ構造（RTO と表記）内に共沈した内包ナノ構造を前駆体として用い ることが有用である. Fig. 6aに示すように, Sun らにより $\mathrm{Sm}(\mathrm{OAc})_{3}$ と $\mathrm{Co}(\mathrm{OAc})_{2}(\mathrm{OAc}=$ アセテート $)$ の熱分解によっ て $\mathrm{SmCo}-\mathrm{O}(7 \mathrm{~nm})$ ナノ粒子が合成されている ${ }^{73)}$.これらに 加えて， 60-220 nm の範囲で粒径制御可能なさまざまな形態 の $\mathrm{Sm}(\mathrm{Co}$ or $\mathrm{Fe})-\mathrm{O}$ ナノ粒子が, $\mathrm{Sm}(\mathrm{acac})_{3}$ および $\mathrm{Co} / \mathrm{Fe}(\mathrm{acac})_{2}$ の熱分解 (Fig. 6b-j $)^{74)}$ またはオレイン酸 $\mathrm{SmCo}$ 錯体の熱分解 $(\text { Fig. 6k-s })^{75)}$ で直接合成されている. $\mathrm{Sm}(\mathrm{OH})_{3}-\mathrm{Co}$ ナノロッ ド76) やウニ様構造 ${ }^{77)}, \mathrm{Sm}(\mathrm{OH})_{3}-\mathrm{Co}(\mathrm{OH})_{2}$ ナノフレーク ${ }^{78,79)}$, $\mathrm{SmCo}-\mathrm{O}$ ナノファイバー ${ }^{80,81)}$ などの形態をもつ $\mathrm{SmCo}-\mathrm{O}$ ナノ 粒子が，超音波照射 ${ }^{76)}$, 水熱 /ソルボサーマル反応 ${ }^{77-79)}$, 電 界紡糸法 ${ }^{80,81)}$ によって合成できる。これら内包ナノ構造の R 量が固溶体形成の臨界濃度以下の場合, 上記と同様の方法で
$\mathrm{R}$ ドープ T-Oナノ構造体を合成できる ${ }^{81-85)}$ ５ $5 \mathrm{~nm}-1 \mu \mathrm{m}$ の範 囲でさまざまな形状・粒径をもつ $\mathrm{R}$ ドープ $\mathrm{Fe}_{2} \mathrm{O}_{3}$ や $\mathrm{Fe}_{3} \mathrm{O}_{4} （ \mathrm{R}$ $=\mathrm{Sm}, \mathrm{Eu}, \mathrm{Gd}, \mathrm{Tb}, \mathrm{Ho}, \mathrm{Er}, \mathrm{Y})$ ナノ粒子を，熱分解 ${ }^{82-84)}$ ，水熱 反応 ${ }^{85)}$ ，超音波照射 ${ }^{86)}$ で得ることができる．R 組成が 20 at.\% 未満のこれら前駆体は， $\mathrm{RT}_{12}$ 磁性メゾスコピック粒子の合成 に適している。

多元素 R-T 磁性メゾスコピック粒子の組成制御に最も簡 易で有用な手法は, $\mathrm{R}-\mathrm{O}$ と $\mathrm{T}-\mathrm{O}$ の混合ナノ粒子（以下 $[\mathrm{T}-$ O, R-O J ナノ粒子と表記）を合成することである。 これは, 化学量論が出発物質の仕込み比によって正確に決まるワン ポット液相化学合成で前駆体を合成する手法である。通常, $\mathrm{Sm}_{2} \mathrm{O}_{3} / \mathrm{Sm}(\mathrm{OH})_{3}, \mathrm{Co} / \mathrm{Co}-\mathrm{O} / \mathrm{Co}(\mathrm{OH})_{2} / \mathrm{CoOOH}, \mathrm{Fe} / \mathrm{Fe}-\mathrm{O}$ ナノ 粒子の混合物が, 還元熱分解 ${ }^{87)}$, ソルボサーマル反応 ${ }^{88)}$, 共 沈 ${ }^{89-96)}$, 超音波処理 ${ }^{97)}$ で得られる. ゾルゲル法, すなわち, 高温でのポリネットワークゲルプロセスでの R-O ゲルと $\mathrm{T}-$ $\mathrm{O}$ ゲルの混合物形成とその焼成処理により, 超微細酸化物 ナノ粒子の混合物を容易かつ効率的に生成させることがで
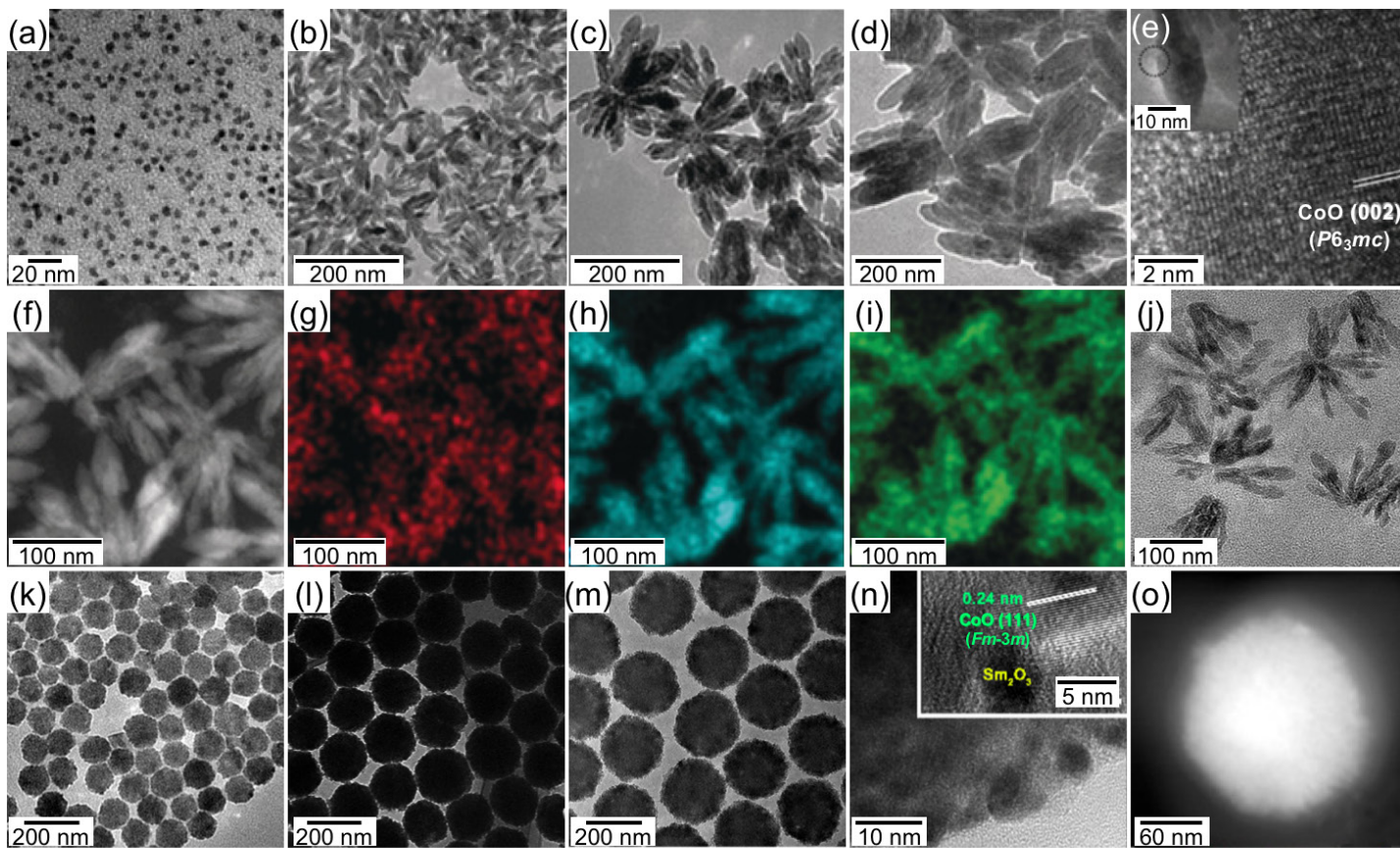

(p)
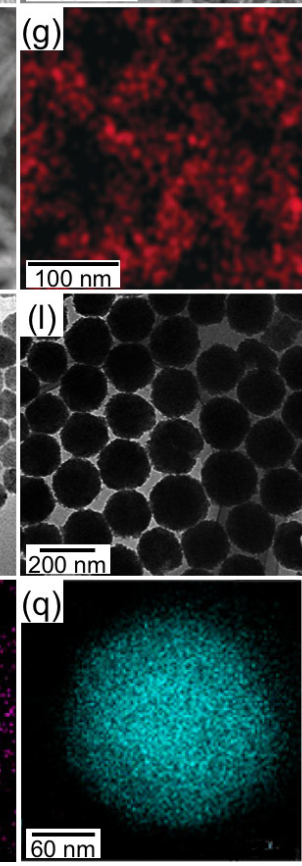
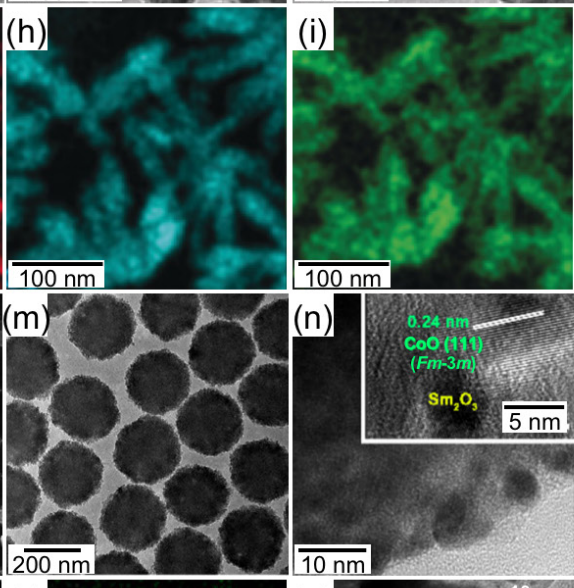

(r)

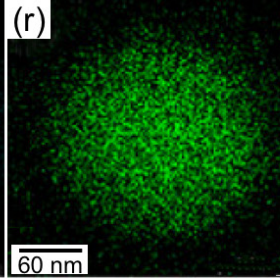

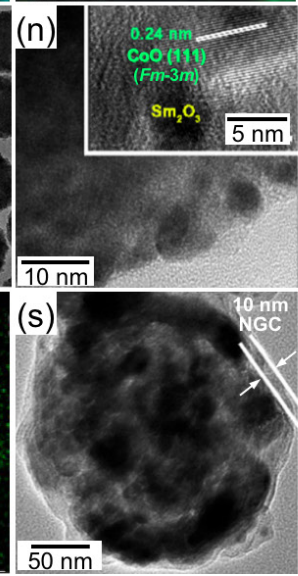

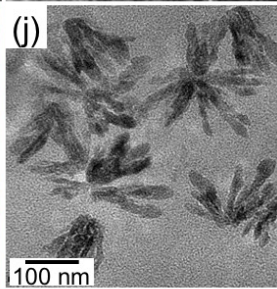

(o)

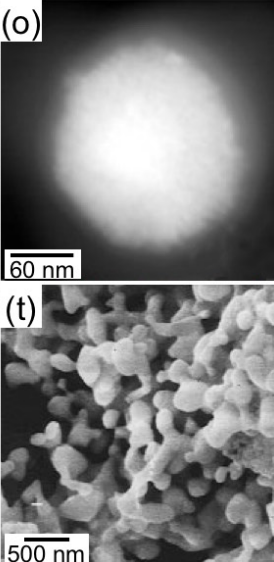

Fig. 6 Chemically-synthesized nanostructured precursors. (a) TEM image of Sm-O encapsulated CoO $(F d-3 m)$ NPs $(7 \mathrm{~nm}, \mathrm{Sm}: \mathrm{Co}=1: 3.6)$. (b-d) TEM images of Sm-O encapsulated $\mathrm{CoO}\left(P 6_{3} m c\right)$ multipods (Sm:Co = 1:4.5): (b) $60 \pm 10 \times 10 \pm 3 \mathrm{~nm}$, (c) $110 \pm 20 \times 25 \pm 5 \mathrm{~nm}$, and $220 \pm 40 \times 45 \pm 5 \mathrm{~nm}$. (e) HRTEM (high-resolution TEM) image of an enlarged part of a nanorod (inserted). (f) HAADF-STEM (high-angle annular dark-field scanning TEM) image and (g-i) elemental mapping images of Sm (g), Co (h), and O (i) of the multipods shown in (c). (j) TEM image of the multipods (shown in (c)) embedded into a $\mathrm{CaO}$ matrix. (k-m) TEM images of Sm-O encapsulated $\mathrm{CoO}(F d-3 m) \mathrm{NPs}:(\mathrm{k}) 110 \pm 8 \mathrm{~nm},(\mathrm{l}) 150 \pm 12 \mathrm{~nm}$, and $(\mathrm{m}) 200 \pm 15 \mathrm{~nm}$. (n) HRTEM image of a section of one $200 \mathrm{~nm}$ NP shown in $(\mathrm{m})$, showing a mixture of smaller CoO and Sm-O NPs. (o) HAADF-STEM image and (p-r) elemental mapping images of Sm (p), Co (q), and O (r) of one representative $200 \mathrm{~nm}$ NP shown in (m). (s) TEM image of one $200 \mathrm{~nm}$ NP (shown in (m)) coated with a $10 \mathrm{~nm}$ layer of $\mathrm{NGC}$ (N-doped graphitic carbon). (t) SEM image of $\mathrm{Fe}_{2} \mathrm{O}_{3}, \mathrm{NdFeO}_{3}$, and $\mathrm{Fe}_{2}\left(\mathrm{MoO}_{4}\right)_{3}$ mixed NPs (ca. 200 nm). (a) Reproduced with permission from [73]. Copyright 2020 The Royal Society of Chemistry. (b-j) Reprinted with permission from [74]. Copyright 2020 Wiley VCH. $(k-t)$ Reproduced with permission from [75,98]. Copyright 2020 American Chemical Society. 
きる ${ }^{98-100)}$. Fig. 6t に示すように，ゲル中の Rイオンと Tイオ ンの濃度を変えることにより, 酸化物ナノ粒子の粒径を約 $10 \mathrm{~nm}$ 数百 $\mathrm{nm}$ の広い範囲で制御できる ${ }^{98)}$. 均一な組成を もち笚分散で粒径制御可能な T/T-O@R-O およびRT-Oナノ 構造前駆体は，分散剂マトリックス $(\mathrm{CaO}$, グラファイトな ど）に埋め込むことができ (Fig. 6j $)^{74,78,79) ， ま た ， そ の ま ま ~}$ 他の層 $(\mathrm{CaO}$, 酸化グラフェン $(\mathrm{GO})$, 窒素ドープグラファ イト状カーボンなど）で被覆しコア@シェル構造にするこ とができるため $(\text { Fig. 6s })^{73,75,76)}$, R-T 磁性メゾスコピック粒 子の微細構造の最適化に極めて有用である. 混合ナノ粒子 戦略は, 埋め込み法でのみ一部成功しているが, R-T 磁性メ ゾスコピック粒子の微細構造の速度論的制御には限度があ $3^{88-92,100)}$. 混合ナノ粒子は粒径を制御しにくいが組成制御が 容易であるため, 多元素 R-T 磁性メゾスコピック粒子の合 成が可能である ${ }^{988}$.

\section{3 多元素 R-T 磁性メゾスコピック粒子の合成}

$\mathrm{Sm}_{2} \mathrm{Fe}_{17} \mathrm{~N}_{3}, \quad(\mathrm{Nd}, \mathrm{Zr})(\mathrm{Fe}, \mathrm{Co}, \mathrm{Ti})_{12} \mathrm{~N}, \quad(\mathrm{Sm}, \mathrm{Zr})(\mathrm{Fe}, \mathrm{Co}, \mathrm{Ti})_{12}$ に代表 される，大きな $H_{\mathrm{a}}$ ，大きな $M_{\mathrm{s}}$, 高い $T_{\mathrm{c}}$ をもつ多元素 $\mathrm{R}-\mathrm{T}$ 金 属間化合物は, 現代の永久磁石応用に打いて $\mathrm{Nd}_{2} \mathrm{Fe}_{14} \mathrm{~B}$ に取っ て代わる最も有望な候補である（Fig. 1)。しかしながら， R カチオンの大きな負の還元電位（例えば, $\mathrm{Sm}^{3+}:-2.304 \mathrm{~V}$, $\left.\mathrm{Nd}^{3+}:-2.323 \mathrm{~V}\right)$ と $\mathrm{R}$ 金属の非常に低い化学的安定性のため, それらの化学合成は依然として大きな課題となっている。一 般に, R および $\mathrm{T}$ カチオンは, 高温固相反応条件下で強力な 還元剂 $\left(\mathrm{CaH}_{2}, \mathrm{Ca}\right.$ など）によって還元され，R および $\mathrm{T}$ 原 子の拡散により R-T 金属間化合物が形成される（還元拡散 プロセス)，還元拡散プロセス前に，還元拡散プロセスでの 炭化物や $\mathrm{C}$ 格子間化合物の生成を回避するため, 焼成によ りナノ構造前駆体から有機物を除去する必要があり, 場合に よっては還元拡散プロセスを促進するため焼成前駆体の水 素予備還元を行う必要があるだろう。この R-T 磁性メゾス コピック粒子合成では, 高温下還元拡散プロセスでの焼結や 大気下での酸化という一般的な問題に我々は直面する，優 れた方策としては, Section 2 で述べたように, 安定した材料 でナノ構造前駆体を被覆することで, 高温固相反応条件下 で生成する磁性メゾスコピック粒子を安定化し，大気酸化 を防ぐ方法がある．化学合成法では，単純な二元 $\mathrm{R}-\mathrm{T}$ 磁性 メゾスコピック粒子の合成に成功している，実際，数 nm〜 数 $\mu \mathrm{m}$ の広い範囲で粒径制御可能な $\mathrm{SmCo}_{5}$ や $\mathrm{Sm}_{2} \mathrm{Co}_{17}$ 磁性入 ゾスコピック粒子が合成されている られた磁性メゾスコピック粒子は，一般的な溶媒に分散可 能で $74,75,91,100)$ ，永久磁性材料でこれまでに報告された最高の 室温 $\mu_{0} H_{\mathrm{c}}=7.2 \mathrm{~T}^{91)}$ に達する極めて大きな $H_{\mathrm{c}}$ をもち, さらに 高温での高い耐酸化性を有している ${ }^{75} . \mathrm{SmCo}_{5}$ 磁性メゾスコ ピック粒子の化学合成は, 以前の総説に詳しく記述されて いる ${ }^{63}$. このように, ナノ構造前駆体は, 幅広い液相化学合 成法によって容易に合成でき，化学合成された $\mathrm{SmCo}_{5}$ 磁性 メゾスコピック粒子の興味深い結果が, $\mathrm{Sm}_{2} \mathrm{Fe}_{17} \mathrm{~N}_{3}$ や (R, Zr) $(\mathrm{Fe}, \mathrm{Co}, \mathrm{M})_{12}(\mathrm{R}=\mathrm{Nd}, \mathrm{Sm} ; \mathrm{M}=\mathrm{Ti}, \mathrm{V}, \mathrm{Cr}, \mathrm{Mn}, \mathrm{Co}, \mathrm{Mo}, \mathrm{W}, \mathrm{Al}, \mathrm{Si}$,
Ga）化合物の化学合成の引き金となっている.これら化 合物の磁性メゾスコピック粒子とそれらの室温磁気特性を Table 1 にまとめる.

3.1 $\mathrm{Sm}_{2} \mathrm{Fe}_{17} \mathrm{~N}_{3}$ 磁性メゾスコピック粒子

$\mathrm{R}_{2} \mathrm{~T}_{17}$ 金属間化合物を代表する $\mathrm{Sm}_{2} \mathrm{Fe}_{17}\left(\mathrm{Th}_{2} \mathrm{Zn}_{17}\right.$ 型, $\left.R-3 m\right)$ 化合物は, 比較的低い $\mu_{0} M_{\mathrm{s}}=1.03 \mathrm{~T}$, 非常に低い $\mu_{0} H_{\mathrm{a}}<1 \mathrm{~T}$, および非常に低い $T_{\mathrm{c}}=116^{\circ} \mathrm{C}$ をつ ${ }^{100-102)} . \mathrm{Sm}_{2} \mathrm{Fe}_{17}$ 化合物に窒 素原子を格子間ドープすると, $\mathrm{Sm}_{2} \mathrm{Fe}_{17} \mathrm{~N}_{3}\left(\mathrm{Th}_{2} \mathrm{Zn}_{17}\right.$ 型, $\left.R-3 m\right)$ 化合物が形成され ${ }^{19,101-103)}$ ，その本質的な磁気特性は， $\mu_{0} M_{\mathrm{s}}=$ $1.57 \mathrm{~T}, \mu_{0} H_{\mathrm{a}}=26 \mathrm{~T}, T_{\mathrm{c}}=473^{\circ} \mathrm{C}$ に大幅に増加し ${ }^{19}, \mathrm{Nd}_{2} \mathrm{Fe}_{14} \mathrm{~B}$ 化合物よりも優れている (Fig. 1)。窒素原子が $9 e$ 八面体サ イトに格子間ドープ（Fig. 7) されることにより，単位胞の 体積拡大と $\mathrm{Fe}-\mathrm{Fe}$ 交換相互作用の増加が起こり，その結果

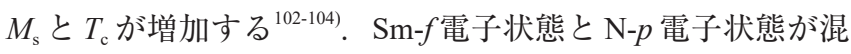
成すると, $\mathrm{Sm}_{2} \mathrm{Fe}_{17}$ の磁化容易面から $\mathrm{Sm}_{2} \mathrm{Fe}_{17} \mathrm{~N}_{3}$ の磁化容易 $c$ 軸に磁化方向が変わり, バンドエネルギーが影響を受け, 大きな一軸結晶磁気異方性が発現する ${ }^{104)} . \mathrm{Sm}_{2} \mathrm{Fe}_{17} \mathrm{~N}_{3}$ は準安 定物質であり, $\mathrm{Sm}_{2} \mathrm{Fe}_{17}$ と窒素またはアンモニアとの気固反 応で，または，メラミン $\left(\mathrm{C}_{3} \mathrm{H}_{6} \mathrm{~N}_{6}\right)$ との固相反応で窒化す ることにより合成される。実際には22)，七クション2で説明 した $\mathrm{Fe}_{3} \mathrm{O}_{4} @ \mathrm{Sm}-\mathrm{O}$ ナノ粒子（約 $30 \mathrm{~nm}$ ）（Fig. 5b）を，空気 中 $1000^{\circ} \mathrm{C}$ で 1 時間焼成し (Fig. 8a, b, g (i)), $900^{\circ} \mathrm{C}$ で 1 時間 水素還元する (Fig. 8c, d, g (ii)). 次に，得られたナノ粒子を アルゴン中 $900^{\circ} \mathrm{C}$ で 1 時間の $\mathrm{Ca}$ 還元拡散反応により $\mathrm{Sm}_{2} \mathrm{Fe}_{17}$ 磁性メゾスコピック粒子に変換し, 続いて窒素中種々の温 度で 10 時間 in situ 窒化（反応系外に取り出さずそのまま窒 化）することにより, $\mathrm{Sm}_{2} \mathrm{Fe}_{17} \mathrm{~N}_{3}$ 磁性メゾスコピック粒子に 変換する (Fig. 8e, f, g (iii)). $\mathrm{Sm}_{2} \mathrm{Fe}_{17} \mathrm{~N}_{3}$ 磁性メゾスコピック 粒子の $H_{\mathrm{c}}$ は，Fig. 8 に示すように窒化温度に依存するが，こ れは窒化プロセスの熱転移に関連している。つまり, 気固 反応での窒化は, 比較的高温 $\left(250-500^{\circ} \mathrm{C}\right)$ でのみ進行し, $\mathrm{Sm}_{2} \mathrm{Fe}_{17} \mathrm{~N}_{x}(0<x \leq 3)$ の窒素濃度は窒化温度の関数になるが, $600^{\circ} \mathrm{C}$ 以上では $\mathrm{Sm}_{2} \mathrm{Fe}_{17} \mathrm{~N}_{3}$ は $\mathrm{SmN}_{x}$ と $\mathrm{Fe}$ に分解する ${ }^{19,105,106)}$. 例えば，Fig. 8e，f，g (iii) および Fig. 9 に示すように， $435^{\circ} \mathrm{C}$ での窒化により形成した $\mathrm{Sm}_{2} \mathrm{Fe}_{17} \mathrm{~N}_{3}$ 磁性メゾスコピック粒子 は, 水洗浄前の等方性試料では $1.9 \pm 1.0 \mu \mathrm{m}$ の粒径と $1.3 \mathrm{~T}$ の 室温 $\mu_{0} H_{\mathrm{c}}$ を有する.

ナノ構造前駆体の観点から, $\mathrm{Sm}_{2} \mathrm{Fe}_{17} \mathrm{~N}_{3}$ 磁性メゾスコピッ ク粒子の粒径は, 反応温度を注意深く操作することで熱力 学的に制御することができる ${ }^{39}$. この目的のために, Section 2 で説明したゾルゲル法によって調製された $\mathrm{Fe}-\mathrm{O}$ と $\mathrm{Sm}-\mathrm{O}$ ナノ粒子の混合物を, 焼成 $\left(500-1000^{\circ} \mathrm{C}\right)$, 水素予備還元 $\left(700-900^{\circ} \mathrm{C}\right), \mathrm{Ca}$ 還元拡散 $\left(900-1000^{\circ} \mathrm{C}\right)$ 処理し, $430^{\circ} \mathrm{C}$ で の in situ 窒化で合成を行った. 得られた $\mathrm{Sm}_{2} \mathrm{Fe}_{17} \mathrm{~N}_{3}$ 磁性メゾ スコピック粒子の粒径は, 処理温度に大きく依存していた。 低温で行われた最初の二つのプロセスは, 次の還元拡散プロ セスでの磁性メゾスコピック粒子の最終粒径を制御するため に非常に重要である。これは，微細なナノ粒子を用いると 低温での $\mathrm{Ca}$ 還元拡散反応が促進され, 微細な磁性メゾスコ ピック粒子を与えるためである。還元拡散反応温度が高いほ 
Table 1 Synthetic details and room-temperature magnetic properties of $\mathrm{Sm}_{2} \mathrm{Fe}_{17} \mathrm{~N}$ and $(\mathrm{R}, \mathrm{Zr})(\mathrm{Fe}, \mathrm{Co}, \mathrm{M})_{12}(\mathrm{R}=\mathrm{Nd}, \mathrm{Sm} ; \mathrm{M}=\mathrm{Ti}, \mathrm{V}, \mathrm{Cr}, \mathrm{Mn}, \mathrm{Co}, \mathrm{Mo}, \mathrm{W}, \mathrm{Al}, \mathrm{Si}$, Ga) MMPs synthesized by a reduction-diffusion (R-D) process. ${ }^{1} \mathrm{~T} / \mathrm{T}-\mathrm{O} @ \mathrm{R}-\mathrm{O}$ NPs: core@ shell structure, RT-O NPs: encapsulation, and [T-O,RO] NPs: mixture of oxide NPs. ${ }^{2}$ Gas-solid nitridation. *High pressure. ${ }^{3}$ Solid-state nitridation. ${ }^{4}$ Dehydrogenation after the rinse with $\mathrm{H}_{2} \mathrm{O}$. ${ }^{5}$ Slowoxidation of $\mathrm{Ca}$ residue before the rinse with $\mathrm{H}_{2} \mathrm{O}$. A typical chemically-synthetic procedure for the synthesis of multielement R-T MMPs composed of calcination, pre-reduction by $\mathrm{H}_{2}$, and (R-D) process using $\mathrm{Ca}$ or $\mathrm{CaH}_{2}$ as reductant.

\begin{tabular}{|c|c|c|c|c|c|c|c|c|c|c|c|c|}
\hline \multirow[b]{2}{*}{ Materials } & \multicolumn{2}{|c|}{ Nanostructured precursors } & \multirow{2}{*}{$\begin{array}{c}\text { Calcination } \\
\text { temperature } \\
\left({ }^{\circ} \mathrm{C}\right)\end{array}$} & \multirow{2}{*}{$\begin{array}{l}\mathrm{H}_{2} \\
\text { reduction } \\
\text { temperature } \\
\left({ }^{\circ} \mathrm{C}\right)\end{array}$} & \multirow{2}{*}{$\begin{array}{c}\mathrm{R}-\mathrm{D} \\
\text { reaction } \\
\text { (Nitridation) } \\
\text { temperature } \\
\left({ }^{\circ} \mathrm{C}\right)\end{array}$} & \multirow{2}{*}{$\begin{array}{l}\text { MMPs } \\
\text { Size } \\
(\mu \mathrm{m})\end{array}$} & \multirow{2}{*}{$\begin{array}{l}T_{\mathrm{c}} \\
\left({ }^{\circ} \mathrm{C}\right)\end{array}$} & \multirow{2}{*}{$\begin{array}{c}M_{\mathrm{s}} \\
(\mathrm{emu} \\
\left.\mathrm{g}^{-1}\right)\end{array}$} & \multirow{2}{*}{$\begin{array}{c}\mu_{0} H_{\mathrm{a}} \\
(\mathrm{T})\end{array}$} & \multirow{2}{*}{$\begin{array}{c}M_{r} \\
(\mathrm{emu} \\
\left.\mathrm{g}^{-1}\right)\end{array}$} & \multirow[b]{2}{*}{$\begin{array}{l}\mu_{0} H_{\mathrm{c}} \\
(\mathrm{T})\end{array}$} & \multirow[b]{2}{*}{ Ref. } \\
\hline & Structural fashion ${ }^{(1)}$ & $\begin{array}{l}\text { Size } \\
(\mathrm{nm})\end{array}$ & & & & & & & & & & \\
\hline \multicolumn{13}{|c|}{$\mathrm{R}_{2} \mathrm{Fe}_{17}\left(\mathrm{Th}_{2} \mathrm{Zn}_{17}, R-3 m\right)$} \\
\hline \multirow{11}{*}{$\mathrm{Sm}_{2} \mathrm{Fe}_{17} \mathrm{~N}$} & & ca. 100 & 500 & 700 & $900\left(430^{2}\right)$ & $0.7 \pm 0.0$ & - & - & - & - & 2.32 & \\
\hline & {$\left[\mathrm{Fe}_{2} \mathrm{O}_{3}, \mathrm{Fe}_{3} \mathrm{O}_{4}, \mathrm{SmFeO}_{3}\right]$} & - & 800 & 900 & $900\left(430^{2}\right)$ & $1.9 \pm 0.8$ & - & - & - & - & ca. 1.8 & [39] \\
\hline & & - & 1000 & 900 & $1000\left(430^{2}\right)$ & $3.5 \pm 1.3$ & - & - & - & - & ca. 1.3 & \\
\hline & $\mathrm{Fe}_{3} \mathrm{O}_{4} @ \mathrm{Sm}-\mathrm{ONPs}$ & ca. 30 & 1000 & 900 & $900\left(435^{3}\right)$ & $1.9 \pm 1.0$ & - & - & - & - & 1.3 & {$[72]$} \\
\hline & $\mathrm{SmFe}-\mathrm{O}$ NPs & $110 \pm 20$ & 185 & $\mathrm{~N} / \mathrm{A}$ & $850\left(600^{2}\right)$ & $0.10 \pm 0.02$ & - & 127.9 & - & - & 1.54 & [74] \\
\hline & \multirow{6}{*}[\mathrm{Fe}-\mathrm{O},\mathrm{Sm}-\mathrm{O}]{$\mathrm{NPs}$} & \multirow{6}{*}{-} & \multirow{6}{*}{ N/A } & 800 & $900\left(420^{2}\right)$ & $0.47 \pm 0.09$ & - & 132 & - & 89 & $2.47^{(4)}$ & \multirow{3}{*}[95]{} \\
\hline & & & & \multirow{2}{*}{700} & $900\left(420^{2}\right)$ & $0.6 \pm 0.2$ & - & 134 & - & 100 & $2.28^{(4)}$ & \\
\hline & & & & & $950\left(420^{2}\right)$ & $0.9 \pm 0.3$ & - & 142 & - & 110 & $1.81^{(4)}$ & \\
\hline & & & & \multirow{3}{*}{600} & $900\left(420^{2}\right)$ & 0.6 & - & - & - & - & $2.78^{5}$ & \multirow{3}{*}{ [96] } \\
\hline & & & & & $950\left(420^{2}\right)$ & 0.9 & - & - & - & - & $2.37^{(5)}$ & \\
\hline & & & & & $980\left(420^{2}\right)$ & 1.5 & - & - & - & - & $2.01^{(5)}$ & \\
\hline
\end{tabular}

$\mathrm{RFe}_{12}\left(\mathrm{ThMn}_{12}\right.$, I4/mmm)

\begin{tabular}{|c|c|c|c|c|c|c|c|c|c|c|c|c|}
\hline $\mathrm{NdFe}_{10} \mathrm{Mo}_{2}$ & {$\left[\mathrm{Fe}_{2} \mathrm{O}_{3}, \mathrm{NdFeO}_{3}, \mathrm{Fe}_{2}\left(\mathrm{MoO}_{4}\right)_{3}\right]$} & ca. 200 & 500 & 700 & 1010 & $3-8$ & - & - & - & - & - & [98] \\
\hline $\mathrm{NdFe}_{10} \mathrm{Mo}_{2} \mathrm{~N}$ & {$\left[\mathrm{Fe}_{2} \mathrm{O}_{3}, \mathrm{NdFeO}_{3}, \mathrm{Fe}_{2}\left(\mathrm{MoO}_{4}\right)_{3}\right]$} & ca. 200 & 500 & 700 & $\begin{array}{c}1010 \\
\left(550-600^{2 *} *\right)\end{array}$ & $3-8$ & 360 & - & - & - & 0.35 & [131] \\
\hline $\mathrm{NdFe}_{10} \mathrm{Mo}_{2}$ & & & & & & & 453 & 65 & - & - & - & \\
\hline $\mathrm{NdFe}_{10} \mathrm{Mo}_{2} \mathrm{H}_{x}$ & & & & & & & 478 & 91 & - & - & - & \\
\hline $\mathrm{NdFe}_{10} \mathrm{Mo}_{2} \mathrm{~N}_{x}$ & & & & & & & 553 & 92 & 7.2 & - & - & \\
\hline $\mathrm{NdFe}_{10.25} \mathrm{Mo}_{1.5} \mathrm{Ti}_{0.25}$ & & & & & & & 483 & 89 & 0.04 & - & - & \\
\hline $\mathrm{NdFe}_{10.25} \mathrm{Mo}_{1.5} \mathrm{Ti}_{0.25} \mathrm{H}_{x}$ & & & & & & & 488 & 93 & 0.04 & - & - & \\
\hline $\mathrm{NdFe}_{10.25} \mathrm{Mo}_{1.5} \mathrm{Ti}_{0.25} \mathrm{~N}_{x}$ & & & & & & & 573 & 103 & 8.2 & - & - & \\
\hline $\mathrm{NdFe}_{10.5} \mathrm{MoTi}_{0.5}$ & & & & & & & 498 & 109 & 1.1 & - & - & \\
\hline $\mathrm{NdFe}_{10.5} \mathrm{MoTi}_{0.5} \mathrm{H}_{x}$ & {$\left[\mathrm{Fe}_{2} \mathrm{O}_{3}, \mathrm{Nd}_{2} \mathrm{O}_{3}, \mathrm{MoO}_{3}, \mathrm{TiO}_{2}\right]$} & - & 500 & $700-800$ & $\begin{array}{c}1100 \\
\left(550-600^{2} *\right)\end{array}$ & - & 508 & 114 & 1.1 & - & - & {$[135,136]$} \\
\hline $\mathrm{NdFe}_{10.5} \mathrm{MoTi}_{0.5} \mathrm{~N}_{x}$ & & & & & & & 608 & 118 & - & - & - & \\
\hline $\mathrm{NdFe}_{10.75} \mathrm{Mo}_{0.5} \mathrm{Ti}_{0.75}$ & & & & & & & 523 & 122 & 1.4 & - & - & \\
\hline $\mathrm{NdFe}_{10.75} \mathrm{Mo}_{0.5} \mathrm{Ti}_{0.75} \mathrm{H}_{x}$ & & & & & & & 533 & 125 & 1.4 & - & - & \\
\hline $\mathrm{NdFe}_{10.75} \mathrm{Mo}_{0.5} \mathrm{Ti}_{0.75} \mathrm{~N}_{x}$ & & & & & & & 673 & 130 & - & - & - & \\
\hline $\mathrm{NdFe}_{11} \mathrm{Ti}$ & & & & & & & 533 & 124 & 1.6 & - & - & \\
\hline $\mathrm{NdFe}_{11} \mathrm{TiH}_{x}$ & & & & & & & 563 & 129 & 2.2 & - & - & \\
\hline $\mathrm{NdFe}_{11} \mathrm{TiN}_{x}$ & & & & & & & 693 & 127 & 8.0 & - & - & \\
\hline
\end{tabular}

ど粒子の焼結により磁性メゾスコピック粒子が大きくなるた め, $\mathrm{Ca}$ 還元拡散プロセスにより $\mathrm{Sm}_{2} \mathrm{Fe}_{17} \mathrm{~N}_{3}$ 磁性メゾスコピッ ク粒子の粒径が決まることになる。結果として, $\mathrm{Sm}_{2} \mathrm{Fe}_{17} \mathrm{~N}_{3}$ 磁性メゾスコピック粒子は, 0.7-3.5 $\mu \mathrm{m}$ の範囲で粒径制御さ れ，異方性試料で 1.3-2.32 Tの範囲の室温 $\mu_{0} H_{\mathrm{c}}$ を示した。焼 成 $500^{\circ} \mathrm{C}$, 水素予備還元 $700^{\circ} \mathrm{C}, \mathrm{Ca}$ 還元拡散プロセス $900^{\circ} \mathrm{C}$ の最低温度で, 最小粒径 $0.69 \mu \mathrm{m}$ の $\mathrm{Sm}_{2} \mathrm{Fe}_{17} \mathrm{~N}_{3}$ 磁性メゾスコ ピック粒子が得られた。 $H_{\mathrm{c}}$ には明らかに粒径依存性があり， $0.69 \mu \mathrm{m}$ の最小粒径で $2.32 \mathrm{~T}$ の最大 $\mu_{0} H_{\mathrm{c}}$ が得られた（Fig. 2a, 青い長方形)。ただし, 上記の合成では, $\mathrm{Ca}$ 還元拡散反応 中の $\mathrm{Sm}$ 蒸発を補償するために, 2: 17の化学量論に対して
25-30 at \% 過剰量の Sm が必要である. Ca の融点 $\left(845^{\circ} \mathrm{C}\right)$ を大きく超える温度でカルシウム熱還元を行う必要があるた め, 熱力学的制御ではさらに微細な粒径にすることができな い. 最近 Sun らは, ナノ構造前駆体の巧みな処理による効果 的な速度論的手法により，粒径と組成がより適切に制御され た $\mathrm{Sm}_{2} \mathrm{Fe}_{17} \mathrm{~N}_{3}$ 磁性メゾスコピック粒子の形成に成功した ${ }^{74)}$. この合成では， $200^{\circ} \mathrm{C}$ で $\mathrm{Ca}(\mathrm{acac})_{2}$ を熱分解することにより， 立方体状 $\mathrm{SmFe}-\mathrm{O}$ ナノ粒子 $(110 \mathrm{~nm})$ を $\mathrm{CaO}$ で完全に被覆 後, $185^{\circ} \mathrm{C}$ で 5 時間焼成し，アルゴン中 $850^{\circ} \mathrm{C}$ で 30 時間 $\mathrm{Ca}$ 還元することで $\mathrm{Sm}_{2} \mathrm{Fe}_{17}$ 磁性メゾスコピック粒子を得た．次 に, $\mathrm{Sm}_{2} \mathrm{Fe}_{17}$ 磁性メゾスコピック粒子を $\mathrm{C}_{3} \mathrm{H}_{6} \mathrm{~N}_{6}$ と混合し, 


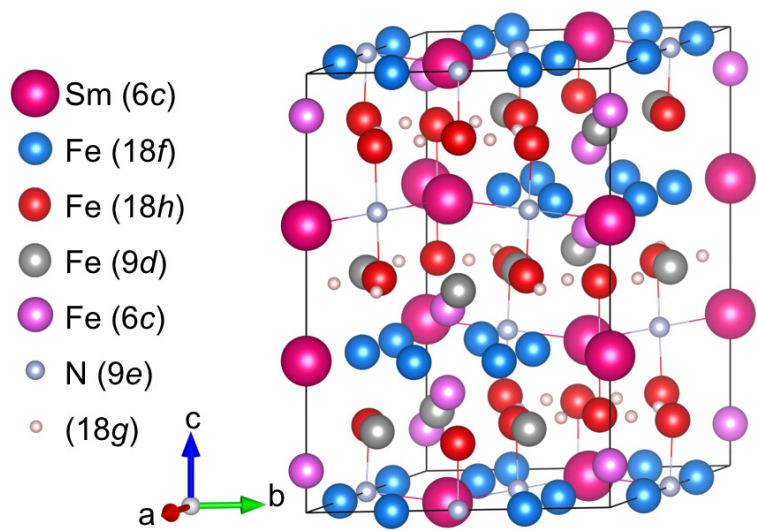

Fig. 7 Crystal structure of $\mathrm{Sm}_{2} \mathrm{Fe}_{17} \mathrm{~N}_{3}\left(\mathrm{Th}_{2} \mathrm{Zn}_{17}, R-3 m\right)$ compound.
アルゴン中 $600^{\circ} \mathrm{C} て ゙ 6$ 時間アニールすることで, $100 \mathrm{~nm}$ の $\mathrm{Sm}_{2} \mathrm{Fe}_{17} \mathrm{~N}_{3}$ 磁性メゾスコピック粒子が生成した。全体の合成 では, Sm 損失を補うために2:17の化学量論に対してわずか 2 at \% だけ立方体状 $\mathrm{SmFe}-\mathrm{O}$ ナノ粒子の組成を過剩にした.

得られた $\mathrm{Sm}_{2} \mathrm{Fe}_{17} \mathrm{~N}_{3}$ 磁性メゾスコピック粒子は, 通常の溶媒 によく分散し, PEG（ポリエチレングリコール）に埋め込ん だ異方性 $\mathrm{Sm}_{2} \mathrm{Fe}_{17} \mathrm{~N}_{3}$ 試料で $1.54 \mathrm{~T}$ の室温 $\mu_{0} H_{\mathrm{c}}$ を示した。この $H_{\mathrm{c}}$ 值は, 粒径 $(100 \mathrm{~nm})$ が $\mathrm{Sm}_{2} \mathrm{Fe}_{17} \mathrm{~N}_{3}$ の単一ドメイン臨界サ イズ $\left(D_{\mathrm{sd}}=\right.$ 約 $\left.390 \mathrm{~nm}\right)$ よりも小さいため，先に報告された 值よりも小さくなった ${ }^{36)}$. この方法では, 前駆体の粒径を大 きくすることで， $D_{\text {sd }}$ に近いより大きな粒径の $\mathrm{Sm}_{2} \mathrm{Fe}_{17} \mathrm{~N}_{3}$ 磁 性メゾスコピック粒子が生成し, 非常に大きな $H_{\mathrm{c}}$ が得られ るだろう。
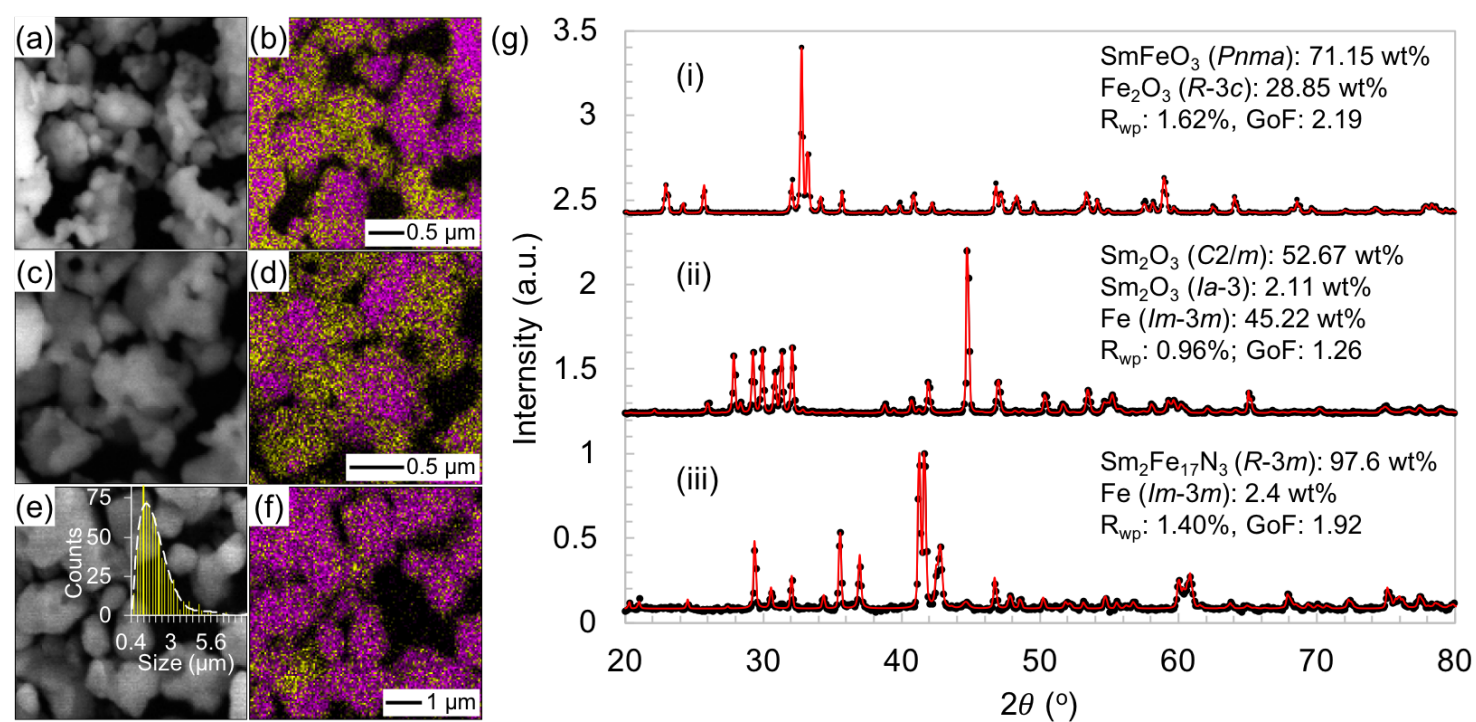

Fig. 8 Structural analysis of chemically synthesized $\mathrm{Sm}_{2} \mathrm{Fe}_{17} \mathrm{~N}_{3}$ MMPs $(R-3 m, 1.9 \pm 1.0 \mu \mathrm{m})$. (a, c, e) SEM images, (b, d, f) energy-dispersive spectroscopy elemental maps (Fe K edge: purple, Sm L edge: yellow), and (g) Rietveld refinement XRD patterns of $\mathrm{Fe}_{3} \mathrm{O}_{4} @ \mathrm{Sm}-\mathrm{O}$ NPs calcined at $1000^{\circ} \mathrm{C}$ for $1 \mathrm{~h}$ (a, b, g (i)), subsequently reduced by $\mathrm{H}_{2}$ at $900^{\circ} \mathrm{C}$ for $1 \mathrm{~h}$ (c, d, g (ii)), and $\mathrm{Sm}_{2} \mathrm{Fe}_{17} \mathrm{~N}_{3}$ MMPs synthesized by Ca R-D at $900^{\circ} \mathrm{C}$ for $1 \mathrm{~h}$ in $\mathrm{Ar}$ and in situ nitridation at $435^{\circ} \mathrm{C}$ for $10 \mathrm{~h}$ in $\mathrm{N}_{2}$ (e, f, g (iii)). Inset in (e) shows the grain size distribution of the $\mathrm{Sm}_{2} \mathrm{Fe}_{17} \mathrm{~N}_{3}$ MMPs. Reproduced with permission from [72]. Copyright 2020 the Chemical Society of Japan.
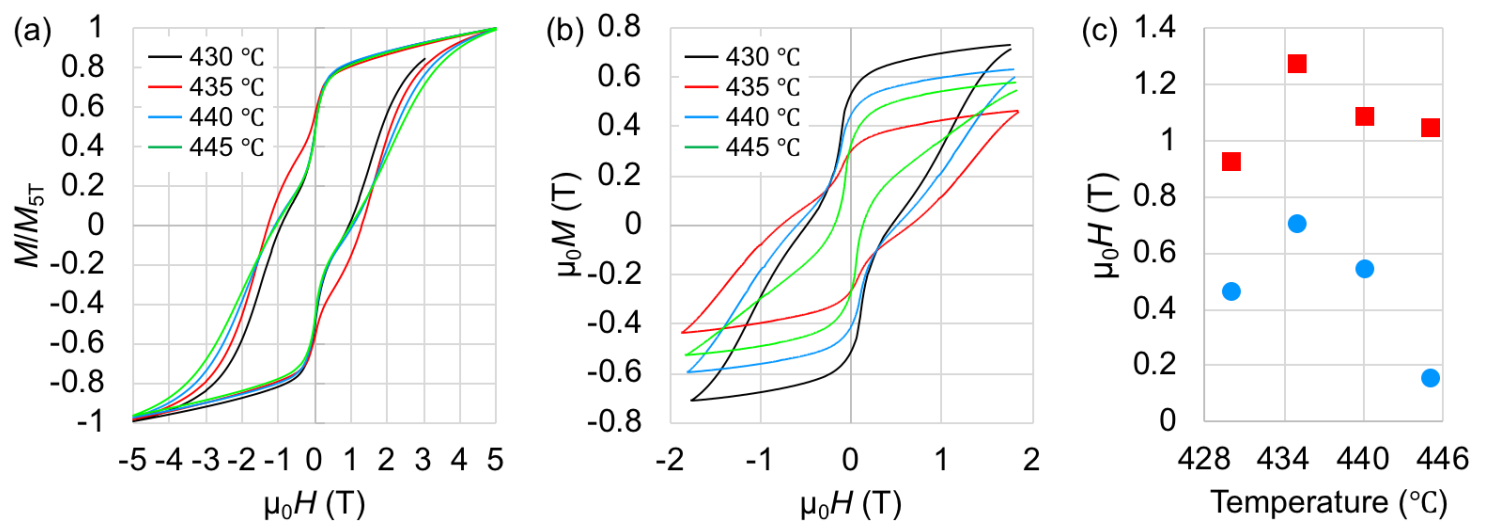

Fig. 9 Room-temperature magnetic properties of $\mathrm{Sm}_{2} \mathrm{Fe}_{17} \mathrm{~N}_{3}$ MMPs $(R-3 m, 1.9 \pm 1.0 \mu \mathrm{m})$ formed by in situ nitridation of $\mathrm{Sm}{ }_{2} \mathrm{Fe} \mathrm{e}_{17} \mathrm{MMPs}$ at various temperatures for $10 \mathrm{~h}$. (a, b) M-H curves before (a) and after (b) the rinse with $\mathrm{H}_{2} \mathrm{O}$. (c) Nitriding-temperature dependence of coercivity (red rectangles: before the rise with $\mathrm{H}_{2} \mathrm{O}$, blue circles: after the rinse with $\mathrm{H}_{2} \mathrm{O}$ ). Replotted with permission from [72]. Copyright 2020 the Chemical Society of Japan. 


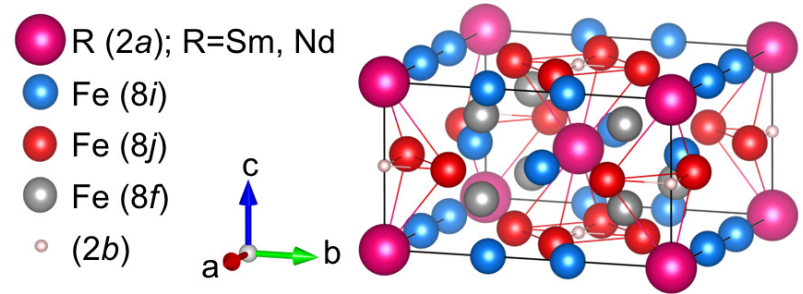

Fig. 10 Crystal structure of $\mathrm{RFe}_{12}\left(\mathrm{ThMn}_{12}, I 4 / \mathrm{mmm}\right)$ compounds $(\mathrm{R}=$ $\mathrm{Sm}, \mathrm{Nd})$.

\section{$3.2 \mathrm{RT}_{12}$ 磁性メゾスコピック粒子}

$\mathrm{NdFe}_{12} \mathrm{~N}\left(\mathrm{ThMn}_{12}\right.$ 型, I4/mmm) および $\mathrm{Sm}(\mathrm{Fe}, \mathrm{Co})_{12}\left(\mathrm{ThMn}_{12}\right.$ 型, I4/mmm) 化合物は, 希土類元素希薄永久磁石で最も有望 な候補である。というのも, その薄膜は, 非常に大きな $M_{\mathrm{s}}$ と $H_{\mathrm{a}}$ (Fig. 1), $(B H)_{\max }$ 理論限界值 $550 \mathrm{~kJ} \mathrm{~m}^{-3}$ および $630 \mathrm{~kJ} \mathrm{~m}^{-3}$, 高い $T_{\mathrm{c}}$ 值 $550^{\circ} \mathrm{C}$ おび $586^{\circ} \mathrm{C}$ をそれぞれ有しており，すべ ての特性が $\mathrm{Nd}_{2} \mathrm{Fe}_{14} \mathrm{~B}$ を上回っている ${ }^{15,20,107-109)}$. 最近, アモル ファスホウ素の結晶粒界をもつカラム状結晶粒 (40 nm) で 構成される異方性 $\mathrm{Sm}\left(\mathrm{Fe}_{0.8} \mathrm{Co}_{0.2}\right)_{12}-\mathrm{B}$ 膜が実現された。この膜 は, $1.2 \mathrm{~T}$ の大きな室温 $\mu_{0} H_{\mathrm{c}}, \quad 1.5 \mathrm{~T}$ の $\mu_{0} M_{\mathrm{r}}$ ，および非常に小 さな温度依存 $H_{\mathrm{c}}$ を示し, $\mathrm{T} \geq 150^{\circ} \mathrm{C}$ での優れた安定性が期待 される ${ }^{110)}$. 残念ながら, それらは準安定相であるため, 永 久磁石の作製に必要なバルク体では実現されていない. バル ク体合成のため, Fe を安定化元素 $\mathrm{M}(\mathrm{M}=\mathrm{Ti}, \mathrm{V}, \mathrm{Cr}, \mathrm{Mn}, \mathrm{Co}$, $\mathrm{Mo}, \mathrm{W}, \mathrm{Al}, \mathrm{Si}, \mathrm{Ga})$ で部分的に置換することができ, Fig. 10 に 示すように，安定化元素に応じて $8 f, 8 i, 8 j$ サイトが優先的 に置換される。例えば, $\mathrm{Ti}, \mathrm{V}, \mathrm{Mo}$ では $8 i, \mathrm{Co}$ と $\mathrm{Si}$ では $8 f$ と $8 j, \mathrm{Ga}$ では $8 j$ サイトの Fe が置換される ${ }^{12,13,17,18,40-50,106,111-117)}$. Fig. 1 の Tiの例に示すように, 高濃度の M で置換すると, Co を除いて $M_{\mathrm{s}}$ が大きく減少する. Co 置換すると, SlaterPauling 曲線に基づき $M_{\mathrm{s}}$ が増加するが，これは，フェルミ準 位より下の majority-spin 状態密度の増加で理解される ${ }^{114,117)}$.

低 $\mathrm{M}$ 置換濃度の化合物を安定化し， $M_{\mathrm{s}}$ を合理的に増加させ るには, $2 a$ サイトで $\mathrm{Sm}$ または $\mathrm{Nd}$ を原子番号の小さい他の $\mathrm{R}$ 元素 (Zr, Y など) に置換することが考えられるが (Fig. 10), Fig. 1 に示すように, Zr の場合 $H_{\mathrm{a}}$ が減少する 置換化合物は, 非常に高い温度でも安定であることが分 かっている ${ }^{127)}$. 置換による安定化は, 軌道混成に不利な構 造において原子間距離の局所的不整合が減少することで理 解でき ${ }^{121)}$ ，置換化合物の生成エネルギーが低くなる ${ }^{114,126)}$. $\mathrm{Nd}(\mathrm{Fe}, \mathrm{M})_{12}$ の $2 b$ 八面体サイトへの格子間窒素ドーピング (Fig. 10) は, $M_{\mathrm{s}}$ と $H_{\mathrm{a}}$ を増加させるために非常に重要であり, $\mathrm{N}-p(2 b)$ と Fe- $d(8 j)$ の混成による磁気モーメントと結晶 場パラメーター $\left\langle r^{2}\right\rangle A_{2}^{0}$ の増加で説明できる ${ }^{128,129)}$.

このような魅力的な $H_{\mathrm{a}}$ 值と精力的な研究にもかかわらず, 十分な $H_{\mathrm{c}}$ をもつ $\mathrm{RT}_{12}$ 磁性メゾスコピック粒子はまだ実現さ れておらず，報告されている $H_{\mathrm{c}}$ 值は対応する $H_{\mathrm{a}}$ の $10 \%$ 未満 である ${ }^{40-50,111,112,124)}$. 以下の重大な問題により, $\mathrm{RT}_{12}$ 化合物の 硬磁性体としての実現性が低くなっている。 まず，Fig. $2 \mathrm{~b} に$ 示すように, $\mathrm{RT}_{12}$ 磁性メゾスコピック粒子の粒径と形状が,
特に sub- $\mu \mathrm{m}$ の範囲で十分に最適化されていない ${ }^{40-50,111,112,124)}$ 第二に，典型的な $\mathrm{RT}_{12}$ 相とともに形成される平衡相は強磁 性であるため, $\mathrm{Nd}$ 相との共晶反応によって結晶粒界がうま く形成される $\mathrm{Nd}_{2} \mathrm{Fe}_{14} \mathrm{~B}$ とは異なり, 従来の方法では適切な 非磁性結晶粒界相を導入できない委21,111,130). 最後に, $\mathrm{RT}_{12}$ 化 合物は通常, 比較的高温で溶融するため, 液相焼結によっ

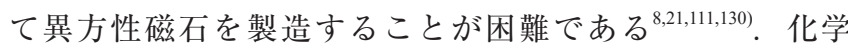
合成された最適微細構造をもつ $\mathrm{RT}_{12}$ 磁性メゾスコピック粒 子は, 十分緻密な異方性磁石への焼結に適しているかもし れないが, 合成が非常に困難である。典型的な合成では, Section 2 で記述したように, $\mathrm{Fe}_{2} \mathrm{O}_{3}\left(P 4_{1} 2_{1} 2, R-3 c\right), \mathrm{NdFeO}_{3}$ (Pnma), $\mathrm{Fe}_{2}\left(\mathrm{MoO}_{4}\right)_{3}\left(P 2_{1} / c, P b c n\right)$ ナノ粒子 (約 $\left.200 \mathrm{~nm}\right)$ の混合物 (Fig. 6t) を, $700^{\circ} \mathrm{C}$ での水素還元で $\mathrm{Fe}(\mathrm{Mo})$ 合金 $(I m-3 m)$ および $\mathrm{Nd}_{2} \mathrm{O}_{3}(C 2 / m, P-3 m 1)$ ナノ粒子に変換し, その後 $1010^{\circ} \mathrm{C}$ で 4 時間の $\mathrm{CaH}_{2}$ 還元拡散により $\mathrm{NdFe}_{10} \mathrm{Mo}_{2}$ $(I 4 / \mathrm{mmm})$ 磁性メゾスコピック粒子（約 3-8 $\mu \mathrm{m})$ に変換す る $(\text { Fig. 11a, b })^{98)}$. 酸化物ナノ粒子の粒径は, $\mathrm{NdFe}_{10} \mathrm{Mo}_{2}$ 磁 性メゾスコピック粒子の粒径を制御する上で重要である。つ まり，微細な酸化物ナノ粒子 (約 $50 \mathrm{~nm}$ ) では, $\mathrm{CaH}_{2}$ 還元 拡散反応が低温（例えば $960^{\circ} \mathrm{C}$ ) かつ短時間で行えるため, 微細な $\mathrm{NdFe}_{10} \mathrm{Mo}_{2}$ 磁性メゾスコピック粒子が得られることに なる ${ }^{98,131)} . \mathrm{NdFe}_{10} \mathrm{Mo}_{2}$ は, より高い反応温度 $\left(550-600^{\circ} \mathrm{C}\right)$ 以外は, Section 3.1 で説明した $\mathrm{Sm}_{2} \mathrm{Fe}_{17} \mathrm{~N}_{3}$ の合成と同じ手順 で窒化することができ, 得られた $\mathrm{NdFe}_{10} \mathrm{Mo}_{2} \mathrm{~N}$ 磁性メゾスコ ピック粒子（約 3-8 $\mu \mathrm{m} ）$ は 0.35T の室温 $\mu_{0} H_{\mathrm{c}}$ を示した ${ }^{131)}$. Table 1 に示すように, この方法は, 一連の三元, 四元, 五 元 R(Fe,M $)_{12} \mathrm{X} \quad(\mathrm{R}=\mathrm{Nd}, \mathrm{Y}, \mathrm{Nb}, \mathrm{Tb}, \mathrm{Er} ; \mathrm{M}=\mathrm{Ti}, \mathrm{Mo}, \mathrm{W}, \mathrm{Si} ; \mathrm{X}=\mathrm{N}$, H）磁性メゾスコピック粒子の合成に適用できる ${ }^{131-136)}$. Fe や $\mathrm{TiFe}_{2}$ 相などの不純物をほとんど含まない $\mathrm{Sm}(\mathrm{Fe}, \mathrm{M})_{12} \mathrm{X}$ 相を 形成するには，Ca還元拡散プロセスでの $\mathrm{Sm}$ 蒸発を補償する ために, 1:12 の化学量論を 2-10 at\% 過剩にする必要がある. $\mathrm{R}(\mathrm{Fe}, \mathrm{M})_{12} \mathrm{X}$ 相の形成には，非常に高い温度 $\left(960-1100^{\circ} \mathrm{C}\right)$ で 長時間（4-8 時間）反応する必要があるため, 得られる磁性 メゾスコピック粒子の粒径は 3-8 $\mu \mathrm{m}$ となる. $\mathrm{Sm}_{2} \mathrm{Fe}_{17} \mathrm{~N}_{3}$ に適 用できる熱力学的粒径制御は，このような高温反応における メゾスコピックスケールの $\mathrm{RT}_{12}$ にはもはや使用できない. 磁性メゾスコピック粒子の焼結を抑制するため混合酸化物ナ ノ粒子を分散剤マトリックス $(\mathrm{CaO}, \mathrm{GO}$ など）に埋め込む ような速度論を通して, 粒径をある程度制御することができ る.より効果的な速度論的アプローチとして，全元素を均一 組成の単一ナノ粒子に組み入れた内包ナノ構造を前駆体と して利用する方法が挙げられる (Fig. 6a-s)。我々は, Section 2 で述べた $\mathrm{Sm}-\mathrm{O}, \mathrm{Zr}-\mathrm{O}, \mathrm{Ti}-\mathrm{O}$ 内包 $\mathrm{CoFe}_{2} \mathrm{O}_{4}(F d-3 m)$ ナノ 粒子 $(5 \mathrm{~nm})$ を用いた五元 $(\mathrm{Sm}, \mathrm{Zr})(\mathrm{Fe}, \mathrm{Co}, \mathrm{Ti})_{12}$ 磁性メゾスコ ピック粒子の合成にこの方法を適用した，その結果，部分 的に粒径制御できる超微細 $(\mathrm{Sm}, \mathrm{Zr})(\mathrm{Fe}, \mathrm{Co}, \mathrm{Ti})_{12}$ 磁性メゾスコ ピック粒子の合成に成功した．得られた $(\mathrm{Sm}, \mathrm{Zr})(\mathrm{Fe}, \mathrm{Co}, \mathrm{Ti})_{12}$ 磁性メゾスコピック粒子は，磁場配向に対し比較的大きな室 温 $H_{\mathrm{c}}$ と高い磁化率を示し, 大きな $(B H)_{\max }$ をもつ異方性バル ク磁石が創製できた。これらの可能性を考慮すると，前駆体 

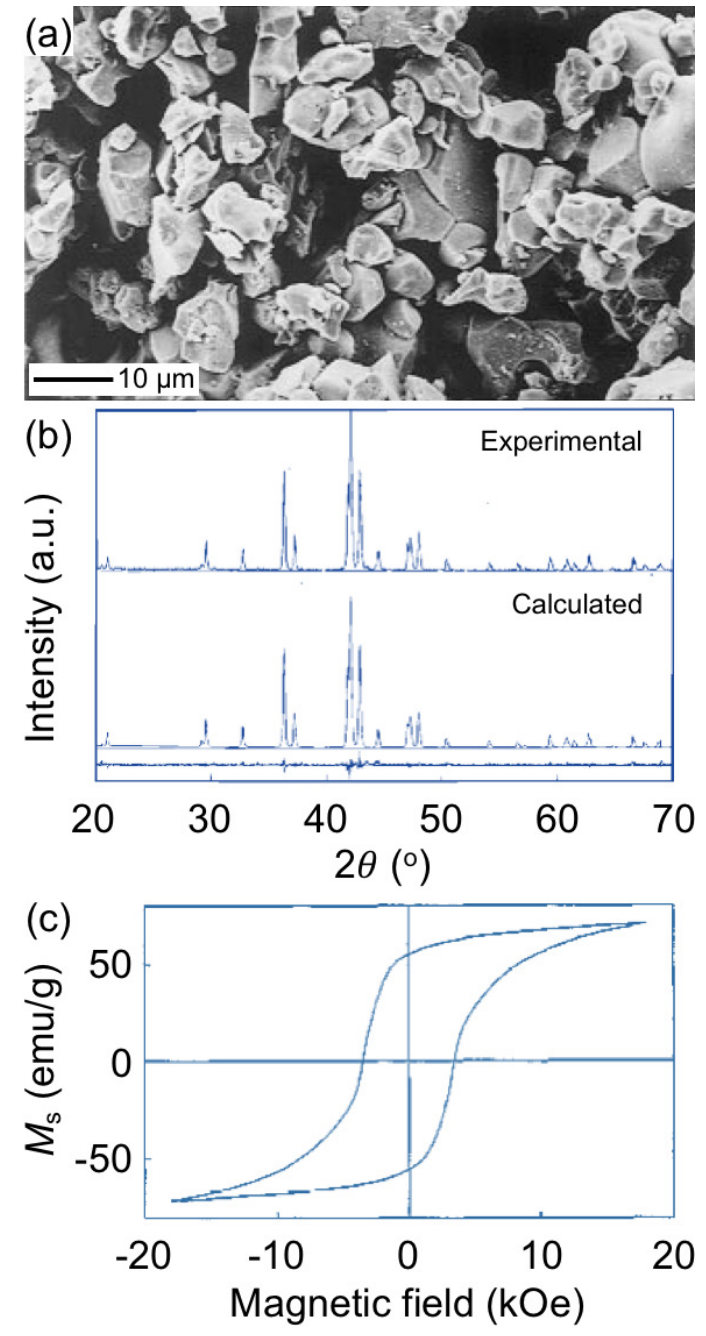

Fig. 11 Structural analysis and room-temperature magnetic properties of chemically synthesized $\mathrm{NdFe}_{10} \mathrm{Mo}_{2}$ and $\mathrm{NdFe}_{10} \mathrm{Mo}_{2} \mathrm{~N}$ MMPs (I4/mmm, 3-8 $\mu \mathrm{m}$ ). (a) SEM image and (b) XRD patterns of $\mathrm{NdFe}_{10} \mathrm{Mo}_{2}$ MMPs synthesized using $\mathrm{CaH}_{2} \mathrm{R}-\mathrm{D}$ at $1010^{\circ} \mathrm{C}$ for $4 \mathrm{~h}$. (c) $\mathrm{M}-\mathrm{H}$ curve of $\mathrm{NdFe}_{10} \mathrm{Mo}_{2} \mathrm{~N}$ MMPs synthesized by nitridation of $\mathrm{NdFe}_{10} \mathrm{Mo}_{2}$ MMPs, showing $\mu_{0} H_{\mathrm{c}}$ of $0.35 \mathrm{~T}$. (a, b) Reproduced with permission from [98]. Copyright 2020 American Chemical Society. (c) Reprinted with permission from [131]. Copyright 2020 Elsevier.

として内包ナノ構造を用いることによる速度論的粒径制御を 一歩前進させることで, $1 \mu \mathrm{m}$ 未満の粒径を達成することが できるだろう。

$3.3 \mathrm{R}-\mathrm{T}$ 磁性メゾスコピック粒子の酸化と水素化

R-T 磁性メゾスコピック粒子の化学合成にはカルシウム熱 還元が含まれるため, 副生成物 $\left(\mathrm{CaO}, \mathrm{CaCO}_{3}\right.$ など $)$ の生成 と還元剂 $\left(\mathrm{CaH}_{2}, \mathrm{Ca}\right.$ など $)$ の残存が不可避である。したがっ て, 精製プロセスが必要となるが, R-T 磁性メゾスコピック 粒子を高純度化し磁気特性を改善することは依然として困難 な問題である，精製の洗浄郕として水溶液を使用すると，副 生成物が生成することが分かっており，合成直後の R-T 磁 性メゾスコピック粒子の磁気特性にある程度影響を及ぼすこ とになる ${ }^{81}$. 一般に, 水洗による $\mathrm{R}-\mathrm{T}$ 磁性メゾスコピック粒 子の酸化と水素化は不可避の副反応である． R-T 磁性メゾス
コピック粒子が一度大気下, 特に酸性溶液に晒されると, $\mathrm{R}$ 元素はイオン化ポテンシャルが低いため容易に酸化され表面 酸化物を形成し, 磁気性能が減少する。最近, Sm-Co 抒上 び $\mathrm{Nd}_{2} \mathrm{Fe}_{14} \mathrm{~B}$ 磁性メゾスコピック粒子を非常に効果的に精製 し耐酸化性を向上させる新しい洗浄プロセスが，Choa らに よって報告された ${ }^{81)}$.この手法では, $\mathrm{NH}_{4} \mathrm{Cl}$ のメタノール溶 液が洗浄剂として使用されて打り, $\mathrm{Ca}$ と $\mathrm{CaO}$ が $\mathrm{NH}_{4} \mathrm{Cl}$ と反 応し $\mathrm{NH}_{3}$ とメタノール可溶性 $\mathrm{CaCl}_{2}$ を形成する。 その結果, HRTEM 測定から磁性メゾスコピック粒子の表面酸化やダ メージは観察されず， Sm-Co 磁性メゾスコピック粒子の $M_{\mathrm{s}}$ 理論值に近い值まで $M_{\mathrm{s}}$ が大幅に改善された。大気の影響を 受けやすいナノスケール R-T 磁性メゾスコピック粒子の場 合, 状沉は高温でより深刻になる。長期にわたる激しい酸化 に対する表面保護は，実際の応用，特に高温での応用にとっ て非常に重要である。最近Sunらは，広い温度範囲での高 性能ナノ磁石応用に向けた $\mathrm{SmCo}_{5}$ ナノ粒子の化学合成と安 定化に関する新しい手法を実証した ${ }^{75}$. 特に, $\mathrm{Sm}_{2} \mathrm{O}_{3}$ と $\mathrm{CoO}$ からなる $\mathrm{SmCo}-\mathrm{O} ナ ノ$ 粒子を窒素ドープグラファイト状炭 素 (NGC) 層で被覆し (Fig. 6s), $\mathrm{CaO}$ マトリックスに埋め 込み, $850^{\circ} \mathrm{C}$ で $\mathrm{Ca}$ 還元することで, $\mathrm{SmCo}_{5} @ \mathrm{NGC}$ 磁性メゾ スコピック粒子が生成した. 得られた $\mathrm{SmCo}_{5} @ \mathrm{NGC}$ 磁性メ ゾスコピック粒子は酸化に対して非常に安定であり, 室温で 5 日間または $100^{\circ} \mathrm{C} て ゙ 48$ 時間大気暴露した後でも，それぞ れ $99.2 \%$ または $98.3 \%$ の磁化を維持できた. 酸化による分解 を防ぐためにも， R-T 磁性メゾスコピック粒子を酸化から保 護することが必要である. $\left(\mathrm{Sm}_{0.8} \mathrm{Zr}_{0.2}\right)\left(\mathrm{Fe}_{0.75} \mathrm{Co}_{0.25}\right)_{11.5} \mathrm{Ti}_{0.5}$ 相は, ほほ無酸素雲囲気 $\left(P_{\mathrm{O}_{2}}<10^{-15} \mathrm{~Pa}\right)$ で少なくとも $1100^{\circ} \mathrm{C}$ ま では安定しているが, 比較的高い酸素分圧下 $\left(P_{\mathrm{O}_{2}}>10 \mathrm{~Pa}\right)$ では $427^{\circ} \mathrm{C}$ 以上で分解されることが分かった ${ }^{127}$.

水溶液を使用した洗浄プロセスでの残留 $\mathrm{Ca}$ と $\mathrm{H}_{2} \mathrm{O}$ の発 熱反応で R-T 磁性メゾスコピック粒子が水素化されると, $\mathrm{Sm}_{2} \mathrm{Fe}_{17} \mathrm{~N}_{3}$ 磁性メゾスコピック粒子の $H_{\mathrm{c}}$ が大幅に低下する ことが分かっている ${ }^{72,95,99}$. Fig. 9 に見られるように, 蒸留 水で洗浄した $\mathrm{Sm}_{2} \mathrm{Fe}_{17} \mathrm{~N}_{3}$ 磁性メゾスコピック粒子の $H_{\mathrm{c}}$ は, 合成直後の試料の 40-80\%減少する。これは, H 原子が $18 g$ 四面体サイト（Fig. 7）に侵入し， $H_{\mathrm{a}}$ の減少を引き起こすた めと考えられる ${ }^{137,138)}$. 真空中でのアニーリングにより水素 ドープ $\mathrm{Sm}_{2} \mathrm{Fe}_{17} \mathrm{~N}_{3}$ 磁性メゾスコピック粒子を脱水素しても, $H_{\mathrm{c}}$ は回復しないことも明暸に観察されている ${ }^{95)}$. その結果, $\mathrm{Sm}_{2} \mathrm{Fe}_{17} \mathrm{~N}_{3}$ 磁性メゾスコピック粒子 $(0.6 \mu \mathrm{m})$ は, 合成直後, 蒸留水での洗浄後, 洗浄と $200^{\circ} \mathrm{C}$ 減圧下での脱水素後の異方 性試料で, $2.8 \mathrm{~T}, 1.56 \mathrm{~T}, 2.28 \mathrm{~T}$ の室温 $\mu_{0} H_{\mathrm{c}}$ を示した。水素 のその場生成を回避するために, 洗浄前に残留 $\mathrm{Ca}$ を $\mathrm{CaO}$ へ ゆっくりと酸化させると, 合成直後の $\mathrm{Sm}_{2} \mathrm{Fe}_{17} \mathrm{~N}_{3}$ 磁性メゾス コピック粒子の $H_{\mathrm{c}}$ が保持された ${ }^{96}$. しかしながら, 酸化に 上り水に不溶の $\mathrm{Sm}_{2} \mathrm{O}_{3}$ や $\mathrm{CaCO}_{3}$ 不純物も生成され, $M_{\mathrm{s}}$ が低 下する，先に述べたように 下1) $^{81} \mathrm{NH}_{4} \mathrm{Cl} /$ メノール溶液を用 いて精製すると, 不純物を選択的に洗浄し, 水素のその場 生成を回避することができ，これは分散可能な $\mathrm{Sm}_{2} \mathrm{Fe}_{17} \mathrm{~N}_{3}$ 磁 性メゾスコピック粒子の合成にも拡張できる゙ ${ }^{74)} . \mathrm{Sm}_{2} \mathrm{Fe}_{17} \mathrm{~N}_{3}$ 
化合物で観察されたものとは異なり, $\mathrm{RT}_{12}$ 化合物の $2 b$ 八 面体サイトへ優先的に水素が格子間ドーピングされると (Fig. 10)， $M_{\mathrm{s}}, H_{\mathrm{a}}$ ，および $T_{\mathrm{c}}$ が大きくなることが分かって いる ${ }^{132-135,139-147)}$. 水素が格子間ドーピングされると， $H_{\mathrm{a}}$ は結 晶場の増加と $c$ 軸に沿った $4 f$ 電子殼の局所対称性の変化に より増大し， $M_{\mathrm{s}}$ と $T_{\mathrm{c}}$ はそれぞれ単位胞の体積膨張と強い $\mathrm{Fe}-\mathrm{Fe}$ 交換相互作用により増大する ${ }^{139-147)}$.

\section{R-T/T 交換結合ナノコンポジット磁石}

硬磁性／軟磁性交換結合ナノコンポジット磁石は，硬磁 性成分と軟磁性成分に対応する大きな $H_{\mathrm{a}}$ と $M_{\mathrm{s}}$ に起因する大 きな $(B H)_{\max }$ をもつことができるため，長い間高性能永久磁 石の潜在的な候補であった ${ }^{148,149)}$. R 元素危機の中, ナノコン ポジット磁石には, 現在必要とされている大きな $(B H)_{\max }$ と 150-200 $\mathrm{C}$ の動作温度をもつ R 元素希薄永久磁石という条件 を満たす可能性がある。微細構造係数 $\alpha^{25-29)}$ で表される交換 結合相互作用の有効性は， $D_{\mathrm{s}} \delta_{\mathrm{w}}$ に反比例する。ここで， $D_{\mathrm{s}}$ は軟磁性相のサイズであり, $\delta_{\mathrm{w}}=\pi \sqrt{A_{\mathrm{ex}} / K_{1}}$ は, 硬磁性相の 磁壁幅である ${ }^{148,149)}$ 。効果的な交換結合相互作用には，軟磁 性相サイズが十分に小さく（異方性バルクナノコンポジッ 卜磁石の場合は $D_{\mathrm{s}}<2 \delta_{\mathrm{w}}$ ), 硬磁性相サイズが軟磁性相の交 換長 $\left(l_{\mathrm{ex}}\right)$ に近い必要がある ${ }^{148-151)}$. これらの原理を考慮する と, 硬磁性材料を用いる交換結合ナノコンポジット磁石の開

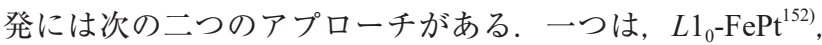
$\mathrm{Nd}_{2} \mathrm{Fe}_{14} \mathrm{~B}^{153,154)}, \mathrm{SmCo}_{5}{ }^{87,155-158)}, \mathrm{Sm}_{2} \mathrm{Fe}_{17} \mathrm{~N}_{3}{ }^{150)}$ など, $K_{1}$ が大き く $\delta_{\mathrm{w}}$ が小さい材料を用いるアプローチである. というのも, これらの大きな $H_{\mathrm{a}}$ が小さな $D_{\mathrm{s}}\left(D_{\mathrm{s}}<\right.$ 約 $\left.10 \mathrm{~nm}\right)$ に対応す る小さな $M_{\mathrm{s}}$ を補償するからである ${ }^{148,149)}$ ，もう一つは， $L 1_{0}$ $\mathrm{FePd}^{159-161)}$ や $\mathrm{HfCo}_{7}{ }^{162)}$ など，中程度の $K_{1}$ と比較的大きな $\delta_{\mathrm{w}}$ を もつ材料を用いるアプローチである。これらは， $\alpha$ と $D_{\mathrm{s}}$ に 利得があり，大きな $D_{\mathrm{s}}\left(D_{\mathrm{s}}<\right.$ 約 $\left.20 \mathrm{~nm}\right)$ に対応する大きな $M_{\mathrm{s}}$ は，中程度の $H_{\mathrm{a}}$ を補償できる ${ }^{148,149,161,162)}$. 後者のアプロー チでは， $\alpha$ の利得に比べ $H_{\mathrm{a}}$ の減少が大き過ぎるため, 通常 は用いられない.

上記の微細構造の問題とは別に, R-T/Tナノコンポジット 磁石の合成で明らかに障害となるのは， R および $\mathrm{T}$ 金属が多 くの平衡相および準安定相を形成する可能性があるため，望 ましくない相が形成されることである。一つの解決法とし て, $L 1_{0}-\mathrm{FePd} / \mathrm{Fe}$ ナノコンポジット磁石合成で有効であるこ とが証明されたように ${ }^{159-161)}$, 硬磁性相の平衡相としての軟 磁性相が生成する硬磁性／軟磁性交換結合ナノコンポジッ 卜磁石を設計することである， R-T/Tナノコンポジット磁石 の化学合成では，これまでのところあまり大きな $(B H)_{\max }$ を 得ることができていない. $\mathrm{Sm}_{2} \mathrm{Fe}_{17} \mathrm{~N}_{3}$ の $K_{1}$ は $16.2 \mathrm{MJ} \mathrm{m}^{-3}$ で あり ${ }^{19)}, \mathrm{Sm}_{2} \mathrm{Fe}_{17} \mathrm{~N}_{3}(2.4 \mathrm{~nm}) / \mathrm{Fe}_{65} \mathrm{Co}_{35}(9 \mathrm{~nm})$ の交互多層異方性 ナノコンポジット磁石は, $1 \mathrm{MJ} \mathrm{m}^{-3}$ (120 MG Oe) の巨大な $(B H)_{\max }$ をもつと理論予想されている ${ }^{149)}$. にもかかわらず, 大きな $H_{\mathrm{c}}$ と $M_{\mathrm{r}}$ を達成できる $10 \mathrm{~nm}$ オーダーの結晶粒径をも つそのようなバルク材料がまだないため, $\mathrm{Sm}_{2} \mathrm{Fe}_{17} \mathrm{~N}_{3}$ ナノコ ンポジット磁石の大きな $(B H)_{\max }$ は実現されていない ${ }^{150,151)}$.
この粒径範囲での準安定 $\mathrm{Sm}_{2} \mathrm{Fe}_{17} \mathrm{~N}_{3}$ の合成は非現実的である ため, これまでのところ $\mathrm{Sm}_{2} \mathrm{Fe}_{17} \mathrm{~N}_{3}$ ナノコンポジット磁石は ほとんど注目されていない. $17.2 \mathrm{MJ} \mathrm{m}^{-3}$ の巨大な $K_{1}, 1.07 \mathrm{~T}$ の比較的小さい $\mu_{0} M_{\mathrm{s}}^{36}$ をもち, $\mathrm{R}-\mathrm{T}$ 金属間化合物の中では 容易に化学合成できることから， $\mathrm{SmCo}_{5}$ は硬磁性相としてか なりの注目を集めている ${ }^{87,155-158)}$. 一般に, $\mathrm{SmCo}_{5} / \mathrm{Fe}$ ナノコ ンポジット磁石は, 混合酸化物ナノ粒子の同時 $\mathrm{Ca}$ 還元拡散 によって合成されるが ${ }^{87,155,156)}$ ，その $M_{\mathrm{r}}$ は非常に小さく，し

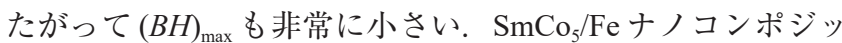
卜磁石で $(B H)_{\max }$ が小さくなる主な理由は, 硬磁性 $\mathrm{SmCo}_{5}$ 相 の容易軸が整列していないためである。異方性 $\mathrm{FePt} / \mathrm{Fe}_{0.8} \mathrm{Ni}_{0.2}$ ナノコンポジット磁石は, 等方性ナノコンポジット磁石の $224 \%(B H)_{\max }$ を向上させられることが実証されている ${ }^{163)}$.

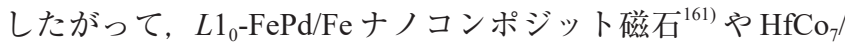
$\mathrm{Fe}_{65} \mathrm{Co}_{35}$ ナノコンポジット磁石 ${ }^{162)}$ での効果が証明されてい る粒子状ナノコンポジット磁石を化学合成することは, 巨 大 $(B H)_{\max }$ を示す異方性ナノコンポジット磁石の製造に非常 に重要である。典型的な合成 ${ }^{157)}$ では，粒子状 $\mathrm{SmCo}_{5} / \mathrm{Co}$ 磁性 メゾスコピック粒子（200 nm，Co- 軟磁性相： 4 wt.\% $)$ が, $960^{\circ} \mathrm{C}$ での $\mathrm{Sm}\left[\mathrm{Co}(\mathrm{CN})_{6}\right] \bullet 4 \mathrm{H}_{2} \mathrm{O} @ \mathrm{GO}$ 磁性メゾスコピック粒子 と $\mathrm{Co}(\mathrm{acac})_{2}$ 添加剂の $\mathrm{Ca}$ 還元拡散により合成された。 その 等方性試料は, $2.07 \mathrm{~T}$ の室温 $\mu_{0} H_{\mathrm{c}}, 0.75$ の $M_{\mathrm{r}} / M_{\mathrm{s}}, 80 \mathrm{~kJ} \mathrm{~m}$ $(10 \mathrm{MG} \mathrm{Oe})$ の $(B H)_{\max }$ を示した. この小さな $(B H)_{\max }$ は, 軟 磁性 Co 相の割合が低いこと (4 wt.\%) や，硬磁性 $\mathrm{SmCo}_{5}$ 相 の結晶粒径が大きすぎること（約 $200 \mathrm{~nm}$ ）で，効果的な交 換結合が生じなかったためである ${ }^{148-151)}$ ，粒子状 $\mathrm{SmCo}_{5} / \mathrm{Co}$ 磁 性メゾスコピック粒子は, 磁気整列で異方性ナノコンポジッ 卜磁石を形成させられるため, $(B H)_{\max }$ の大幅な増加が見込 まれる. $\mathrm{SmCo}_{5} / \mathrm{Fe}($ または $\mathrm{Co})$ ナノコンポジット磁石にお いて，軟磁性相フラクションが増加すると他の相が形成され る可能性があるため, 軟磁性相の割合を高くすることは大き な課題である ${ }^{155,157)}$. この合金化の問題を回避する効果的な 化学合成として，文献に記載されているように ${ }^{156}, \mathrm{SiO}_{2}$ 被 覆 $\mathrm{Fe}$ ナノ粒子を $\mathrm{SmCo}_{5}$ マトリックスに分散させることが挙 げられる，見通しとしてはおそらく，Tが高フラクションの とき $\mathrm{RT}_{12}$ 相の唯一の平衡相であるような $\mathrm{RT}_{12} / \mathrm{T}$ ナノコンポ ジット磁石がよいだろう。残念ながら, $\mathrm{RT}_{12} / \mathrm{T}$ ナノコンポ ジット磁石に関する報告はまだない。

\section{5 結論と展望}

多元素あるいは多相材料である多成分 $\mathrm{R}-\mathrm{T}$ 永久磁性材 料は, この数十年の $\mathrm{Nd}_{2} \mathrm{Fe}_{14} \mathrm{~B}$ 磁石の時代の後に $(B H)_{\max }$ を 「ムーアの法則」に戻すと期待されている，というのも，理 論上の $(B H)_{\max }$ の限界值は $\mu_{0} M_{\mathrm{s}} / 4$ で与えられるが, $M_{\mathrm{s}}$ はさら に増加する可能性があるからである（Fig. 1)。しかし，近年 の理論計算による大きな intrinsic 特性を備えた高性能磁性材 料, 特に $(\mathrm{R}, \mathrm{Zr})(\mathrm{Fe}, \mathrm{Co}, \mathrm{Ti})_{12}(\mathrm{R}=\mathrm{Nd}, \mathrm{Sm})$ 化合物の探索は驚 くべき成果（Fig. 1）を出しているが，対応する磁石の製造 との間に大きなギャップが残っている。この遅れの原因は， 実用上適切な extrinsic 特性を最大にするためにメゾスコピッ 
ク領域での最適な微細構造をもつ化合物の合成と，異方性磁 石の製造に適切な結晶粒界の導入が困難であるからである. 磁性材料粉末の製造で一般的な従来の合成技術ではまだ不十 分であるが，ナノ構造前駆体の液相合成とそれに続く固相反 応で最近進歩を見せている化学合成法は，この課題を克服す るのに適しているかもしれない. ナノ構造前駆体が用いられ るため, 化学的手法は熱力学と速度論で決まる微細構造の制 御範囲を広げることができる，残念ながら，熱力学は，高温 が必要な $\mathrm{RT}_{12}$ 金属間化合物の粒径制御に限界がある。固相 反応に向けたナノ構造前駆体の適切なエンジニアリングが重 要な鍵となる速度論制御にのみ，展望がありそうである。理 想的なナノ構造前駆体は，すべての成分で構成される粒子状 ナノ粒子であり，単分散で組成が均一である必要がある. $\mathrm{R}-\mathrm{T}$ 金属間化合物の合成におけるこれまでの課題に加え, $\mathrm{R}-\mathrm{T} / \mathrm{T}$ ナノコンポジット磁石の合成は, 効果的な交換相互作 用のために $10 \mathrm{~nm}$ オーダーの粒径で R-T 相を達成すること, および， T フラクションの増加に伴う望ましくない相が形成 することなど，新しい問題に直面している，結果として，よ く粒径制御され非常に大きな $H_{\mathrm{c}}$ をもつ単分散 $\mathrm{Sm}_{2} \mathrm{Fe}_{17} \mathrm{~N}_{3}$ 磁性 メゾスコピック粒子が異方性磁石製造のために合成されてい るが, $(\mathrm{R}, \mathrm{Zr})(\mathrm{Fe}, \mathrm{Co}, \mathrm{Ti})_{12}$ 磁性メゾスコピック粒子と R-T/T ナ ノコンポジット磁石の開発はほとんど進展していない. 最適 な微細構造をもつ磁性メゾスコピック粒子が合成されれば, その異方性磁石は, 従来の液相焼結の代わりに, 急速低温電 流焼結法 ${ }^{164)}$ や浸透処理 ${ }^{165)}$ によって製造できる.

\section{謝辞}

本研究は, 文部科学省元素戦略磁性材料研究拠点 (ESICMM) プロジェクトの支援により実施された。

\section{文献}

1) S. Hirosawa, Y. Matsuura, H. Yamamoto, et al.: J. Appl. Phys., 59 (1986) 873-879.

2) M. Sagawa, S. Hirosawa, H. Yamamoto, et al.: Jpn. J. Appl. Phys., 26 (1987) 785-800.

3) Y. Matsuura: J. Magn. Magn. Mater., 303 (2006) 344-347.

4) O. Gutfleisch, M. A. Willard, E. Brück, et al.: Adv. Mater., 23 (2011) 821-842.

5) S. Sugimoto: J. Phys. D: Appl. Phys., 44 (2011) 064001.

6) S. Hirosawa: J. Mag. Soc. Jpn., 39 (2015) 85-95.

7) S. Hirosawa, M. Nishino, S. Miyashita: Adv. Nat. Sci.: Nanosci. Nanotechnol., 8 (2017) 013002.

8) J. M. D. Coey: Perspective and prospects for rare earth permanent magnets. Engineering, 6 (2020) 119-131.

9) T. Miyake, H. Akai: J. Phys. Soc. Jpn., 87 (2018) 041009.

10) H. Akai: Scripta Materialia, 154 (2018) 300-304.

11) D. Weller, A. Moser, L. Folks, et al.: IEEE Trans. Magn., 36 (2000) 10-15.

12) Y. C. Yang, X. D. Zhang, S. L. Ge, et al.: J. Appl. Phys., 70 (1991) 6001-6005.
13) M. Akayama, H. Fujii, K. Yamamoto, et al.: J. Magn. Magn. Mater., 130 (1994) 99-107.

14) S. Sakurada, A. Tsutai, T. Hirai, et al.: J. Appl. Phys., 79 (1996) 4611-4613.

15) Y. Hirayama, Y. K. Takahashi, S. Hirosawa, et al.: Scripta Materialia, 95 (2015) 70-72.

16) S. Suzuki, T. Kuno, K. Urushibata, et al.: J. Magn. Magn. Mater., 401 (2016) 259-268.

17) K. Ohashi, Y. Tawara, R. Osugi, et al.: J. Appl. Phys., 64 (1988) 5714-5716.

18) S. F. Cheng, V. K. Sinha, Y. Xu, et al.: J. Magn. Magn. Mater., 75 (1988) 330-338.

19) T. Iriyama, K. Kobayashi, N. Imaoka, et al.: IEEE Trans. Magn., 28 (1992) 2326-2331.

20) Y. Hirayama, Y. K. Takahashi, S. Hirosawa, et al.: Scripta Materialia, 138 (2017) 62-65.

21) M. A. Gabay, G. C. Hadjipanayis: Scripta Materialia, 154 (2018) 284-288

22) P. Tozman, H. Sepehri-Amin, Y. K. Takahashi, et al.: Acta Materialia, 153 (2018) 354-363.

23) A. Aharoni: Rev. Mod. Phys., 34 (1962) 227-238.

24) W. F. Brown. Micromagnetics, (1963) New York: Wiley.

25) H. Kronmüller: Phys. Stat. Sol. (b), 144 (1987) 385-396.

26) H. Kronmüller, K.-D. Durst, M. Sagawa: J. Magn. Magn. Mater., 74 (1988) 291-302.

27) J. M. D. Coey. Rare-earth iron permanent magnets, (1996) Oxford: Oxford University Press.

28) D. Givord, M. Rossignol, V. M. T. S. Barthem: J. Magn. Magn. Mater., 258-259 (2003) 1-5.

29) R. Skomski: J. Phys.: Condens. Matter., 15 (2003) R841-R896.

30) B. Balamurugan, D. J. Sellmyer, G. C. Hadjipanayis, et al.: Scripta Materialia, 67 (2012) 542-547.

31) N. Poudyal, J. P. Liu: J. Phys. D: Appl. Phys., 46 (2013) 043001

32) M. Yue, Z. Zhang, J. P. Liu: Nanoscale, 9 (2017) 3674-3697.

33) C. Kittel: Phys. Rev., 70 (1945) 965-971.

34) C. Kittel: Rev. Mod. Phys., 21 (1949) 541-583.

35) R. C. O'Handley: Modern Magnetic Materials: Principles and Applications, (200) Weinheim: Wiley-VCH.

36) J. M. D. Coey: Magnetism and Magnetic Materials, (2010) Cambridge, U.K.: Cambridge University Press.

37) N. Imaoka, T. Iriyama, S. Itoh, et al.: J. Alloys Compd., 222 (1995) 73-77.

38) S. Tada, T. Tomimoto, M. Kume: REPM'12 Proc., (2012) 4853.

39) Y. Hirayama, A. K. Panda, T. Ohkubo, et al.: Scripta Materialia, 120 (2016) 27-30.

40) J. Stmeszewski, Y. Z. Wang, E. W. Singleton, et al.: IEEE Trans. Magn., 25 (1989) 3309-3311. 
41) M. Okada, K. Yamagishi, M. Homma: Mater. Trans. JIM, 30 (1989) 374-377.

42) H. Sun, Y. Otani, J. M. D. Coey: J. Appl. Phys., 67 (1990) 4659-4661.

43) Y. Wang, G. C. Hadjipanayis, A. Kim, et al.: J. Appl. Phys., 67 (1990) 4954-4956.

44) S. Sugimoto, A. Kojima, M. Okada, et al.: Mater. Trans., JIM, 32 (1991) 1180-1183.

45) S. Suzuki, N. Inoue, T. Miura: IEEE Tran. Magn., 28 (1992) 2005-2009.

46) L. Bessais, C. Djega-Mariadassou: Phys. Rev. B, 79 (2001) 054412

47) W. Gong, G. C. Hadjipanayis: IEEE Trans. Magn., 28 (1992) 2563-2565.

48) F. E. Pinkerton, D. J. Van Wingerden: IEEE Trans. Magn., 25 (1989) 3306-3308.

49) E. W. Singleton, J. Strzeszewski, J. C. Hadjipanayis, et al.: J. Appl. Phys., 64 (1988) 5717-5719.

50) E. W. Singleton, J. Strzeszewski, G. C. Hadjipanayis: Appl. Phys. Lett., 54 (1989) 1934-1936.

51) K. Strnat, G. Hoffer, J. Olson, et al.: J. Appl. Phys., 38 (1967) 1001-1002.

52) M. Sagawa, S. Fujimura, N. Togawa, et al.: J. Appl. Phys., 55 (1984) 2083-2087.

53) M. Sagawa, S. Fujimura, N. Togawa, et al.: IEEE Trans. Magn., MAG-20 (1984) 1584-1589.

54) J. J. Croat, J. F. Herbst, R. W. Lee, et al.: J. Appl. Phys., 55 (1984) 2078-2082.

55) J. J. Croat, J. F. Herbst, R. W. Lee, et al.: Appl. Phys. Lett., 44 (1984) 148-149.

56) F. J. Cadieu: International Materials Reviews, 40 (1995) $137-$ 148.

57) K. V. S. Rama Rao, G. Markandeyulu, K. G. Suresh, et al.: Bull. Mater. Sci., 22 (1999) 509-517.

58) A. Müller: J. Appl. Phys., 64 (1988) 249-251.

59) T. S. Jang, H. H. Stadelmaier: J. Appl. Phys., 67 (1990) $4957-$ 4959.

60) W. Suski: Powder Metall. Met. Ceram., 36 (1997) 231-241.

61) Y. Liu, D. J. Sellmyer, D. Shindo: Handbook of Advanced Magnetic Materials, (2006) New York: Springer.

62) L. Wu, A. Mendoza-Garcia, Q. Li, et al.: Chem. Rev., 116 (2016) 10473-10512.

63) B. Shen, S. Sun: Chem. Eur. J., 26 (2020) 6757-6766.

64) S. Peng, C. Wang, J. Xie, et al.: J. Am. Chem. Soc., 128 (2006) 10676-10677.

65) Y. Hou, Z. Xu, S. Peng, et al.: Adv. Mater., 19 (2007) 33493352.

66) Q. Wu, L. Cong, M. Yue, et al.: Nanoscale, 12 (2020) 1395813963.

67) K. J. Carroll, D. M. Hudgins, S. Spurgeon, et al.: Chem.
Mater., 22 (2010) 6291-6296.

68) Y. Hou, Z. Xu, S. Sun: Angew. Chem. Int. Ed., 46 (2007) 6329 -6332 .

69) D. Kim, N. Lee, M. Park, et al.: J. Am. Chem. Soc., 131 (2009) 454-455.

70) W. Ge, R. Sato, H. L. Wu, et al.: ChemPhysChem, 16 (2015) 3200-3205.

71) J. Park, K. An, Y. Hwang, et al.: Nat. Mater., 3 (2004) 891895.

72) J. Kim, H. L. Wu, S. Hsu, et al.: Chem. Lett., 48 (2019) 1054 1057.

73) H. Zhang, S. Peng, C. Rong, et al.: J. Mater. Chem., 21 (2011) 16873-16876.

74) B. Shen, C. Yu, A. A. Baker, et al.: Angew. Chem. Int. Ed., 58 (2019) 602-606

75) Z. Ma, M. Yue, H. Liu, et al.: J. Am. Chem. Soc., 142 (2020) 8440-8446

76) B. Shen, C. Yu, D. Su, et al.: Nanoscale, 10 (2018) 8735-8740

77) C. Li, Q. Wu, Z. Ma, et al.: J. Mater. Chem. C, 6 (2018) 85228527.

78) N. Yue, C. Li, Q. Wu, et al.: Chem. Eng. J., 343 (2018) 1-7.

79) W. B. Ali, Q. Wu, Z. M, et al.: J. Magn. Magn. Mater., 499 (2020) 166205

80) J. Lee, T. Y. Hwang, M. K. Kang, et al.: Front Chem., 6 (2018) 18.

81) J. Lee, T. Y. Hwang, H. B. Cho, et al.: Sci. Rep., 8 (2018) 15656.

82) C. R. D. Silva, S. Smith, I. Shim, et al.: J. Am. Chem. Soc., 131 (2009) 6336-6337.

83) L. Yang, Z. Zhou, H. Liu, et al.: Nanoscale, 7 (2015) $6843-$ 6850.

84) K. P. Rice, S. E. Russek, R. H. Geiss, et al.: Appl. Phys. Lett., 106 (2015) 062409.

85) H. Wan, P. Rong, X. Liu, et al.: Adv. Funct. Mater., 27 (2017) 1606821.

86) P. Kowalik, J. Mikulski, A. Borodziuk, et al.: J. Phys. Chem. C, 124 (2020) 6871-6883.

87) G. S. Chaubey, N. Poudyal, Y. Liu, et al.: J. All. Comp., 509 (2011) 2132-2136

88) Z. Ma, S. Yang, T. Zhang, et al.: Chem. Eng. J., 304 (2016) 993-999.

89) Z. Ma, T. Zhang, C. Jiang: Chem. Eng. J., 264 (2015) 610616.

90) Z. Ma, M. Yue, Q. Wu, et al.: Nanoscale, 10 (2018) 10377 10382.

91) Y. Dong, T. Zhang, X. Xia, et al.: Nanoscale, 11 (2019) 1696216967.

92) S. Palaka, M. Yue, Z. Ma, et al.: J. All. Comp., 812 (2020) 151674.

93) H. Tang, M. A. H. Mamakhel, M. Christensen: J. Mater 
Chem. C, 8 (2020) 2109-2116.

94) S. Okada, K. Takagi, K. Ozaki: J. Alloys and Compounds, 663 (2016) 872-879.

95) S. Okada, K. Suzuki, E. Node, et al.: J. Alloys and Compounds, 695 (2017) 1617-1623.

96) S. Okada, E. Node, K. Takagi, et al.: Journal of Alloys and Compounds, 804 (2019) 237-242.

97) T. Y. Hwang, J. Lee, M. K. Kang, et al.: Applied Surface Science, 475 (2019) 986-989.

98) S. F. Liu, J. H. Lin, X. L. Qian, et al.: Chem. Mater., 8 (1996) 2545-2547.

99) B. G. Kelly, K. M. Unruh: IEEE Transactions on Magnetics, 49 (2013) 3349-3352.

100) Z. Ma, J. Liang, W. Ma, et al.: Nanoscale, 11 (2019) 1248412488.

101) J. M. D. Coey, H. Sun: J. Magn. Magn. Mater., 87 (1990) L251-L254.

102) H. Sun, J. M. D. Coey, Y. Gtani, et al.: J. Phys. Condens. Matter, 2 (1990) 6465-6470.

103) Y. Otani, D. P. F. Hurley, H. Sun, et al.: J. Appl. Phys., 69 (1991) 5584-5589.

104) M. Ogura, A. Mashiyama, H. Akai: J. Phys. Soc. Jpn., 84 (2015) 084702.

105) C. N. Christodoulou, T. Takeshita: J. Alloys and Compounds, 202 (1993) 173-182.

106) K. H. J. Buschow: Rep. Prog. Phys., 54 (1991) 1123-1213.

107) T. Sato, T. Ohsuna, M. Yano, et al.: J. Appl. Phys., 122 (2017) 053903.

108) H. Hegde, R. Rani, A. Navarathna, et al.: J. Appl. Phys., 70 (1991) 6345-6347.

109) F. J. Cadieu, H. Hegde, A. Navarathna, et al.: Appl. Phys. Lett., 59 (1991) 875-877.

110) H. Sepehri-Amin, Y. Tamazawa, M. Kambayashi, et al.: Acta Materialia, 194 (2020) 337-342.

111) I. Dirba, J. Li, H. Sepehri-Amin, et al.: J. Alloys and Compounds, 804 (2019) 155-162.

112) I. Dirba, H. Sepehri-Amin, T. Ohkubo, et al.: Acta Materialia, 165 (2019) 373-380.

113) I. Dirba, Y. Harashima, H. Sepehri-Amin, et al.: J. Alloys and Compounds, 813 (2020) 152224.

114) Y. Harashima, K. Terakura, H. Kino, et al.: J App. Phys., 120 (2016) 203904.

115) N. X. Chen, S. Q. Hao, Y. Wu, et al.: J. Magn. Magn Mater., 233 (2001) 169-180.

116) O. Moze, L. Pareti, M. Solzi, et al.: Solid State Commun., 66 (1988) 465-469.

117) M. Matsumoto, T. Hawai, K. Ono: Phys. Rev. Applied, 13 (2020) 064028.

118) S. Suzuki, T. Kuno, K. Urushibata, et al.: AIP Advances, 4 (2014) 117131.
119) N. Sakuma, S. Suzuki, T. Kuno, et al.: AIP Advances, 6 (2016) 056023.

120) M. Gjoka, V. Psycharis, E. Devlin, et al.: J. Alloys and Compounds, 687 (2016) 240-245.

121) K. Kobayashi, S. Suzuki, T. Kuno, et al.: J. Alloys and Compounds, 694 (2017) 914-920.

122) M. Hagiwara, N. Sanada, S. Sakurada: J. Magn. Magn. Mater., 465 (2018) 554-558.

123) T. Kuno, S. Suzuki, K. Urushibata, et al.: AIP Advances, 6 (2016) 025221.

124) T. Kuno, S. Suzuki, K. Urushibata, et al.: Materials Transactions, 60 (2019) 1697-1706.

125) P. Tozman, Y. K. Takahashi, H. Sepehri-Amin, et al.: Acta Materialia, 178 (2019) 114-121.

126) Y. Harashima, T. Fukazawa, H. Kino, et al.: J. Appl. Phys., 124 (2018) 163902.

127) K. Kobayashi, D. Furusawa, S. Suzuki, et al.: Mater. Trans., 59 (2018) 1845-1853.

128) T. Miyake, K. Terakura1, Y. Harashima, et al.: J. Phys. Soc. Jpn., 83 (2014) 043702.

129) Y. Harashima, K. Terakura, H. Kino, et al.: Phys. Rev. B, 92 (2015) 184426.

130) G. C. Hadjipanayis, A. M. Gabay, A. M. Schönhöbel, et al.: Engineering, 6 (2020) 141-147.

131) M. Z. Su, S. F. Liu, X. L. Qian, et al.: J. Alloys Compd., 249 (1997) 229-233.

132) Q. M. Cheng, J. H. Lin, M. Z. Su: Solid State Commun., 106 (1998) 455-458.

133) Q. M. Cheng, J. H. Lin, M. Z. Su: J. Alloys Compd., 269 (1998) 297-300.

134) Q. M. Cheng, J. H. Lin, M. Z. Su: J. Alloys Compd., 272-277 (1998) 6-9.

135) Q. M. Cheng, J. H. Lin, M. Z. Su: J. Alloys Compd., 280 (1998) 310-313.

136) Q. M. Cheng, J. H. Lin, M. Z. Su: App. Phys, Lett., 73 (1998) 2500-2502.

137) C. N. Christodoulou, T. Takeshita: J. Alloys Compd., 198 (1993) 1-24.

138) C. N. Christodoulou, N. Komada: J. Alloys Compd., 222 (1995) 92-95.

139) O. Isnard, M. Guillot, S. Miraglia, et al.: J. Appl. Phys., 79 (1996) 5542-5544.

140) O. Isnard, S. Miraglia, M. Guillot, et al.: J. Alloys Compd., 275-277 (1998) 637-641.

141) M. Morales, M. Bacmann, P. Wolfers, et al.: J. Magn. Magn. Mater., 236 (2001) 83-92.

142) O. Isnard: J. Alloys Compd., 356-357 (2003) 17-21.

143) C. Piquer, F. Grandjean, O. Isnard, et al.: J. Appl. Phys., 95 (2004) 6308-6316.

144) O. Isnard, V. Pop: J. Alloys Compd., 509S (2011) S549-S554. 
145) I. S. Tereshina, S. A. Nikitin, N. Y. Pankratov, et al.: J. Magn. Magn. Mater., 231 (2001) 213-218.

146) I. S. Tereshina, N. Y. Pankratov, E. A. Tereshina, et al.: Phys. Met. Metallogr., 99 (2005) S46-S49.

147) I. S. Tereshina, N. V. Kostyuchenko, E. A. Tereshina-Chitrova, et al.: Sci. Rep., 8 (2018) 3595.

148) E. F. Kneller, R. Hawig: IEEE Trans. Magn., 27 (1991) 35883600.

149) R. Skomski, J. M. D. Coey: Phys. Rev. B, 48 (1993) 1581215816.

150) K. O’Donnell, J. M. D. Coey: J. Appl. Phys., 81 (1997) 63106321.

151) T. Schrefl, R. Fischer, J. Fidler, et al.: J. Appl. Phys., 76 (1994) 7053-7058.

152) H. Zeng, J. Li, J. P. Liu, et al.: Nature, 420 (2002) 395-398.

153) L. Yu, C. Yang, Y. Hou: Nanoscale, 6 (2014) 10638-10642.

154) L. Q. Yu, Y. P. Zhang, Z. Yang, et al.: Nanoscale, 8 (2016) 12879-12882.

155) Y. Hou, S. Sun, C. Rong, et al.: Appl. Phys. Lett., 91 (2007) 153117.
156) B. Shen, A. Mendoza-Garcia, S. E. Baker, et al.: Nano Lett., 17 (2017) 5695-5698.

157) C. Yang, L. Jia, S. Wang, et al.: Sci. Rep., 3 (2013) 3542.

158) Z. Ma, T. Zhang, C. Jiang: RSC Adv., 5 (2015) 89128-89132.

159) T. Teranishi, A. Wachi, M. Kanehara, et al.: J. Am. Chem. Soc., 130 (2008) 4210-4211.

160) N. Sakuma, T. Ohshima, T. Shoji, et al.: ACS Nano, 5 (2011) 2806-2814.

161) K. Matsumoto, R. Sato, T. T. Trinh, et al.: Nanoscale Adv., 1 (2019) 2598-2605.

162) B. Balasubramanian, P. Mukherjee, R. Skomski, et al.: Sci. Rep., 4 (2014) 6265.

163) X. Liu, S. He, J. M. Qiu, et al.: Appl. Phys. Lett., 98 (2011) 222507.

164) K. Takagi, H. Nakayama, K. Ozaki, et al.: J. Magn. Magn. Mater., 324 (2012) 1337-1341.

165) D. Ogawa, X. D. Xu, Y. K. Takahashi, et al.: Scripta Materialia, 164 (2019) 140-144. 